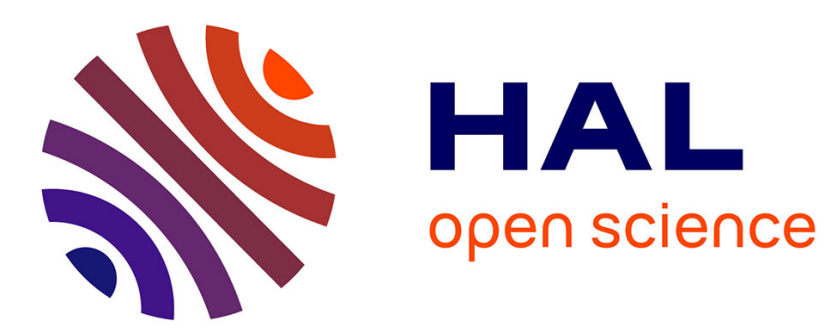

\title{
AN ANALYSIS OF NEW FIRM SURVIVAL USING A HAZARD FUNCTION.
}

Phil Holmes, Andrew John Hunt, Ian Stone

\section{To cite this version:}

Phil Holmes, Andrew John Hunt, Ian Stone. AN ANALYSIS OF NEW FIRM SURVIVAL USING A HAZARD FUNCTION.. Applied Economics, 2009, 42 (02), pp.185-195. 10.1080/00036840701579234 . hal-00582145

\section{HAL Id: hal-00582145 \\ https://hal.science/hal-00582145}

Submitted on 1 Apr 2011

HAL is a multi-disciplinary open access archive for the deposit and dissemination of scientific research documents, whether they are published or not. The documents may come from teaching and research institutions in France or abroad, or from public or private research centers.
L'archive ouverte pluridisciplinaire HAL, est destinée au dépôt et à la diffusion de documents scientifiques de niveau recherche, publiés ou non, émanant des établissements d'enseignement et de recherche français ou étrangers, des laboratoires publics ou privés. 


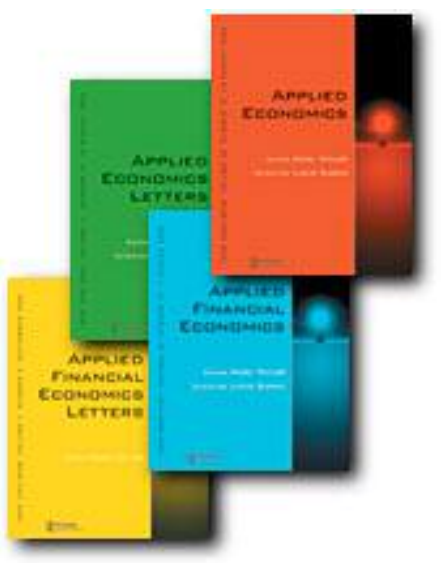

AN ANALYSIS OF NEW FIRM SURVIVAL USING A HAZARD FUNCTION.

\begin{tabular}{|r|l|}
\hline Journal: & Applied Economics \\
\hline Manuscript ID: & APE-06-0367.R1 \\
\hline Journal Selection: & Applied Economics \\
\hline Date Submitted by the \\
Author: & 29 -Jun-2007 \\
\hline Complete List of Authors: & $\begin{array}{l}\text { Holmes, Phil; University of Durham, School of Economics, Finance } \\
\text { and Business } \\
\text { Hunt, Andrew; University of Durham, School of Economics, Finance } \\
\text { and Business } \\
\text { Stone, Ian; University of Durham, School of Economics, Finance } \\
\text { and Business }\end{array}$ \\
\hline JEL Code: & $\begin{array}{l}\text { C41 - Duration Analysis \&lt; C4 - Econometric and Statistical } \\
\text { Methods: Special Topics \&lt; C - Mathematical and Quantitative } \\
\text { and Market Performance \&lt; L - Industrial Organization }\end{array}$ \\
\hline Keywords: & \begin{tabular}{l} 
new firm survival, hazard models, micro-enterprises \\
\hline
\end{tabular} \\
\hline
\end{tabular}

\section{(5) ScholarONE" \\ Manuscript Central}




\title{
AN ANALYSIS OF NEW FIRM SURVIVAL USING A HAZARD \\ FUNCTION
}

by

Phil Holmes, Andrew Hunt and Ian Stone

\begin{abstract}
$\underline{\text { Abstract }}$
A unique dataset is used to provide a detailed examination of the survival of newly-established manufacturing firms in north-east England. Using data on 781 firms established between 1973 and 2001, log-logistic hazard models are estimated separately for (i) micro-enterprises and (ii) small and medium establishments (SMEs). Both micro-enterprises and SMEs show clear evidence of positive duration dependence, followed by negative duration dependence. We find the two firm types are differentially affected by firm-specific and macroeconomic variables. Increases in initial plant size impact negatively on micro-enterprise survival and positively on SME survival.
\end{abstract}

Keywords: new firm survival, hazard models, micro-enterprises.

JEL classification: C41, L10.

Running title: Hazard estimations of new firm survival.

Corresponding author: Andrew Hunt, School of Economics, Finance and Business. University of Durham, Mill Hill Lane, Durham, DH1 3HY, UNITED KINGDOM, Tel: 0191334 5424, Fax: 01913345201.

Phil Holmes and Ian Stone are Professors and Andrew Hunt is a Research Associate in the School of Economics, Finance and Business at the University of Durham 


\section{INTRODUCTION}

In the UK since the early 1980s the birth of new firms has been seen as a major means by which unemployment might be constrained or reduced. As such, a panoply of government initiatives designed to promote small firm start-ups and (to a lesser extent) growth has been introduced (for a discussion of some of the key policies see Storey (1990)). Implicit in these policies has been the assumption that, once established, firms continue to make a contribution to the economy. While firm entry is clearly of importance, arguably duration can be considered to be of greater significance in terms of meeting long-term policy objectives related to employment and the growth of the economy. The current concern to develop policies to help improve the rates of business succession (when the owner wishes to exit) reflects this concern (Stone, et al. 2004). Over the past two decades considerable work has been undertaken on the post-entry performance of new firms (see, for example, Mata and Portugal (2002), Arrighetti and Vivarelli (1999), Audretsch and Mahmood (1995), and Mata and Portugal (1994) $)^{1}$. However, while much attention has been given to factors affecting the birth and death of firms in the UK, and to the duration of firm

\footnotetext{
${ }^{1}$ In addition to these studies there have been others examining post-entry performance and new firm entry, see, for example, Agarwal (1998), Audretsch (1995), Audretsch and Mahmood (1994), Audretsch, Santarelli and Vivarelli (1999), Dunne, Roberts and Samuelson (1988), Fotopoulos and Louri (2000) Geroski (1991), Mahmood (2000), Pérez, Llopis and Llopis (2004), Persson (2004), Segarra and Callejón (2002) and the special edition of the International Journal of Industrial Organisation, edited by Mata and Audretsch (1995).
} 
survival in other countries, to date there has been a paucity of work directly investigating new firm duration in the $\mathrm{UK}^{2}$.

Furthermore, in examining the firm duration issue, all previous studies have undertaken analysis for new firms as a group. This may have resulted in some of the underlying relationships being masked. Therefore, in this study, the approach taken is to use sub-samples based on the characteristics that the literature suggests may be relevant to survival, for example, local vs. non-local ownership and micro as opposed to larger sized firms (SMEs). Interestingly, the result to emerge is that thare are considerable differences between the factors affecting the survival of micro-enterprises and those affecting small and medium

\footnotetext{
2 Dunne and Hughes (1992) examine firm survival for UK companies and Reid (1991) analyses factors helping small entrepreneurial firms to stay in business using a sample of firms in Scotland, but in neither paper is a longitudinal dataset available and both use a sample which does not relate specifically to new firms. In contrast, Taylor (1999) investigates the duration of self-employment spells in Britain using the British Household Panel Survey. However, this involves an analysis of duration at the level of the individual, rather than the firm. Thus the current work can be viewed as being complementary to Taylor's study. McCloughan and Stone (1998) examine survival in the context of the UK, but their work relates to foreign multinational subsidiaries and uses a much smaller sample than is used in the current study. In a comprehensive study, Disney et al (2003) examine entry, exit and survival of UK manufacturing firms. However, this study only relates to establishments with 100 or more employees, does not relate specifically to new firms and examines a relatively short time period (1986-1991) compared to the current study. Li and Hamblin (2003) investigate the effects of manufacturing performance on the survival of UK manufacturing companies' using a relatively small sample of 156 UK wide observations, collected during the 1980s and 1997.
} 
establishments (SMEs) $)^{3,4}$. In the light of this, previous studies may well have resulted in inappropriate policy conclusions being drawn.

This shortage of work on the UK is due primarily to the lack of suitable available datasets to investigate the issue. As Mata and Audretsch note, "in order to analyze the post-entry performance of firms, a large longitudinal database to track firms subsequent to their entry is needed." (1995, p416). To date, such a database has not been available for the UK. The current study utilises a unique, relatively large, database relating to manufacturing firms established in the Wearside area of England over the twenty-nine year period 1973-2001 compiled, over time, by one of the authors. This has been augmented with additional data from the Office of National Statistics. By using this dataset, augmented by other data, together with the hazard rate approach, we are able to analyse firm duration over a long period (1973-2002), and to identify the impact of firm-specific, industry-specific and macroeconomic variables on firm survival. In addition, given the size of the database used, we are able to analyse separately the factors determining the survival of (i) micro-enterprises and (ii) SMEs. Given that there

\footnotetext{
${ }^{3}$ We define micro-enterprises as establishments with total employment at the start-up date of nine or less and SMEs as establishments with total employment at the start-up date of ten or more. It should be noted that some of the establishments we term SMEs are not SMEs in the traditional sense as they are plants of larger enterprises located elsewhere (see section II below for further discussion). However, for convenience we use the terms firm, enterprise and establishment interchangeably in relation to the sample analysed.

${ }^{4}$ It is, of course, the case that a number of studies analyse the impact of firm or plant size on duration by including size as an independent variable (see, for example, Audretsch and Mahmood (1995), McCloughan and Stone (1998), Disney et al. (2003) and Li and Hamblin (2003)).
} 
are strong economic grounds for believing that these two types of enterprise will be affected differently by different variables, it is desirable to model their survival separately. As such, this paper makes an important contribution to our understanding of the post-entry performance of newly-established manufacturing firms in a UK region and provides important implications for government policy designed to promote the survival of new small firms.

While the sample used here relates to one sub-region of the UK only, nonetheless, the results have wider relevance. Industrial performance at either the national or regional level is crucially affected by the ability of newly-established firms and plants to survive and grow. New firms are one means by which a manufacturing economy adjusts its specialisation over time towards more competitive products and they are an important counterbalance to contraction and closure. Similarly, the renewal process can be achieved by the establishment (on green or brownfield sites) of new plants by externally-owned companies. The extent to which the new units thrive and develop impacts upon the components of change and thus the stock of producers over time ${ }^{5}$. Understanding the dynamics of growth at the regional level has attracted increasing attention over recent years. This attention has tended to focus upon the drivers of start-up and in-movement, reflected in the fact that during the study period support was especially generous at the start-up and in-movement phase. This, typically nationally-operated, support may be expected to reduce the death rates of firms in their first few years

\footnotetext{
${ }^{5}$ A regional illustration of the dynamic process relating to foreign direct investment is given in Stone and Peck (1996).
} 
of existence. After this stage fewer support measures could be drawn upon which, combined with the perils known to accompany attempts at growth, would be consistent with rising death rates. After decades of nationally-operated policies relating to industry ${ }^{6}$, the UK has decentralised policy formulation and delivery through the network of Regional Development Agencies. Identifying the factors that influence firm survival within an area that is typical of peripheral UK regions is thus a topic of considerable practical relevance.

To summarise the results, we find that there are considerable differences in the factors affecting the survival of micro-enterprises and SMEs. In particular, it is shown that initial plant size has a negative impact on the survival of microenterprises, but a positive impact on the survival of SMEs, while initial ownership status is not of importance for survival of either enterprise type. It is also shown that both types of enterprises are characterised by positive duration dependence, consistent with the tailing-off of early years assistance and the risks of early years growth, followed by negative duration dependence. This calls into question the results of previous studies that have utilised hazard functions which

\footnotetext{
${ }^{6}$ For example, Wearside had Assisted Area Status for much of the period under review, thus qualifying for the maximum level of central government investment grants for plant and machinery. Additional assistance took forms such as low cost loans (e.g. from the European Coal and Steel Community). Some supplementary regionally/locally administered support was also available such as rent concessions via bodies such as the Washington New Town Corporation and the Tyne and Wear Development Corporation. For a discussion of the frameworks for business support in the earlier part of out sample period see Stone and Stevens (1986), for the latter part of the period see Bank of England (1994-2001) and Deakins and Freel (2006).
} 
assume duration dependence to be monotonically increasing or decreasing (e.g. the Weibull distribution).

The remainder of the paper is organised as follows: section II discusses methodological issues and the empirical design used in this study. In section III we set out the relationships to be examined in this paper between firm survival and economic variables. Results are presented and discussed in section IV and section $\mathrm{V}$ provides a summary and concluding remarks.

\section{METHODOLOGICAL ISSUES AND EMPIRICAL DESIGN}

In order to investigate factors affecting firm survival, it is necessary to examine data concerning the duration of the life of a firm. A major problem encountered when analysing duration data is that of censored data. In this study censored data refers to those firms which were still alive at the time when the data was last updated. To overcome the problems caused by censored data it is necessary to consider not only whether a firm will cease trading, but also the length of time the firm trades. This can be achieved by using a hazard rate approach. The hazard rate model of the duration of the life of a firm provides a statistical representation of the relation between the survival time of a firm and certain explanatory variables. The model is a natural one for working with data which has a longitudinal element, as it provides a method for dealing with censored data. The hazard rate approach involves modelling the conditional probability that a firm will cease trading over a specified period. The hazard rate can be thought of as the rate at which firms die after duration $t$, given that they are alive at least until time $\mathrm{t}$. 
An important concept in considering the hazard function is duration dependence. If the hazard function for a particular distribution slopes upwards (downwards), then the distribution has positive (negative) duration dependence. Positive (negative) duration dependence implies that the likelihood of failure at time t, conditional on duration up to $t$, is increasing (decreasing) in $t$. Different parametric specifications of the hazard function display different duration dependence behaviour. Four widely used distributions in economics are the exponential which displays constant duration dependence, the Weibull for which the hazard function is monotonically increasing or decreasing (depending on the value of the relevant parameter), the log-normal and the log-logistic which can both display increasing duration dependence initially, followed by decreasing duration dependence. It is also possible that the log-logistic distribution will display only negative duration dependence. Which behaviour is displayed depends upon the estimated value of the shape parameter. A priori it is not obvious which distribution is most appropriate. In this study all four distributions were used and the log-logistic was chosen on the basis of the loglikelihood values. The results presented in the following section are based on this distribution ${ }^{7}$. With the log-logistic distribution the hazard function is given by:

$$
\lambda(t)=\lambda \rho(\lambda t)^{\rho-1} /\left[1+(\lambda t)^{\rho}\right]
$$

\footnotetext{
${ }^{7}$ In addition, the Cox proportional hazard model was also utilised. The general pattern of results was similar across all specifications. Results from the other specifications are available on request.
} 
where $\lambda(t)$ is the hazard function and $\rho$ is a shape parameter. If $\rho>1$ then there is positive duration dependence followed by negative duration dependence. If $\rho=1$ then there is monotonic negative duration dependence. Explanatory variables (or 'covariates') can be included in the model by letting $\lambda$ be a function of a set of regressors:

$$
\lambda_{i}=e^{-\beta x_{i}}
$$

where $x_{i}$ are variables which affect survival and the parameters are given by $\beta$. Thus, the model is formulated in terms of the effects of explanatory variables on the probability of the firm dying, the hazard function. The sign of the estimated coefficients indicates the direction of the effect of the variable on the hazard function, with a negative coefficient implying shorter durations (increased probability of death) and a positive coefficient longer durations.

Previous studies of the survival of new firms have been constrained by the paucity of available data. In order to undertake detailed analysis of duration, it is necessary to have a sample of firms that is sufficiently large, covers a relatively long time period and is complete in terms of the timing of both births and deaths. In addition, in order to examine the impact of macroeconomic variables on firm survival, it is desirable for the sample to include firms with different start dates. The main database used in this study comprises a unique sample of 781 manufacturing firms in Wearside, North East England that were newlyestablished over the period $1973-2001^{8}$. Of the 781 firms, $318(40.7 \%)$ were

\footnotetext{
${ }^{8}$ The vast majority of these newly-established firms consist of entirely new start-ups within the boundary of Wearside. A small number of the newly-established firms consist of recently formed
} 
still in business ('alive') in 2002 (the end of the sample period), while 463 (59.3\%) had ceased trading ('dead'). Table 1 provides a summary of the number of firms splitting the sample into five year sub-periods by date of establishment (with the exception of the first period which is eight years). It also provides a breakdown by sub-period of those that were alive in 2002, and hence represent truncated observations. Two important empirical issues need to be discussed. First, there is a potential problem caused by heterogeneity of the data. For example, included within the sample are externally-owned sub-units of larger enterprises, while others are completely new start-ups. While this heterogeneity of the sample is potentially problematic, it is mitigated by sub-dividing the sample into micro-enterprises and SMEs and by the use of plant size and ownership status as independent variables. In addition, the construction of the sample has ensured that it does not contain 'dead ducks' (very short-life firms that by their nature have extremely little chance of survival) ${ }^{9}$. Second, it is obvious from Table 1 that there was a large influx of firms in the period 1981-85, with many of these firms subsequently exiting. This raises the question of whether there is a cohort effect affecting this group of entrants. However, it should be noted that the failure rate for this group of firms is much lower than

local firms re-locating from outside the boundary for purposes (typically) of procuring more suitable premises; the remainder consist of externally-owned companies establishing new production facilities in the area via greenfield investment or by taking over facilities vacated by a firm which has gone into liquidation or moved out of the area.

${ }^{9}$ New entrants have been identified using a variety of sources (e.g. local authority and private sector industrial property lists, industrial directories, etc.), verified by either telephone or postal 
that of the firms established earlier (although obviously the latter group have had a longer time in which to fail) and similar to that for that group of firms established in the latter half of the 1980s. More importantly, differences in cohorts through time are taken into account by the inclusion of industry-specific and macroeconomic independent variables.

\section{TABLE 1 HERE}

The database allows the identification for each firm of the date of establishment, the date of closure (if dead), the initial ownership status of the firm (foreign, UK or local), plant size (as measured by the number of employees within the first two years of trading), the 4-digit standard industrial classification (SIC 1992) code for the firm, the total grants received (adjusted to 1990 prices) over the life of the firm to 2002, and the location within the Wearside area (Washington New Town, the former coalfield zone of Houghton, Inner Sunderland, Outer Sunderland). This database information was augmented by data on macroeconomic and industry-specific variables. In particular, use was made of data on average annual short- and long-term real interest rates, average annual effective exchange rates, annual sectoral growth rates, annual sectoral employment growth rates, annual average sectoral wage rates, annual sectoral growth value-added in the UK, annual unemployment rate in the (Northern) Region and the UK, and the 3-

contact at a later date. The data-gathering process is such that very short-life firms (i.e. those existing for just a few months) were excluded from the database. 
digit five-firm concentration ratio at the year of establishment ${ }^{10}$. It is argued that by utilising company-specific, industry-specific and macroeconomic variables data, it should be possible to identify the main factors affecting firm survival.

In estimating the hazard models, the data set is divided into two sub-samples on the basis of plant size at the establishment date. Models are estimated separately for those firms with total employment at the date of establishment of nine or less (micro-enterprises) and those with total employment of ten or more at the date of establishment (SMEs). Within the original dataset were a small number of 'larger' enterprises with over 100 employees at establishment, these were excluded on the grounds that their sizes were a-typical and there is no reliable method to ascertain if these enterprises were drawn from the same population as the rest of the SME cohort ${ }^{11}$. This sub-division of the sample into micro and SME is undertaken to reflect the fact that the variables determining duration are likely to differ between micro-enterprises and SMEs ${ }^{12}$. While it might have been desirable to further sub-divide the SME group, this was not possible due to the

\footnotetext{
${ }^{10}$ Details of the data used in the final estimations and the sources are provided in the Appendix at the end of the paper.

${ }^{11}$ The definitions used here are broadly consistent with those of the European Commission, which defines micro-enterprises as having between 0 and 9 employees and SMEs as having 10 - 499 employees.

${ }^{12}$ In the results reported below this is found to be the case. Indeed, when estimations were undertaken for the entire sample (micro-enterprises and SMEs together), a number of variables found to be significant below, were found to be insignificant, highlighting the importance of differentiating between the two types of firms.
} 
sample size. The sub-division resulted in a sample of 549 for micro-enterprise firms (of which $41 \%$ were alive in 2002) and 232 SMEs (39\% alive in 2002).

\section{RELATIONSHIP BETWEEN FIRM SURVIVAL AND ECONOMIC VARIABLES}

The choice of covariates to be included in the analysis has been determined by prior expectations based on theory and previous empirical studies. As indicated above, it is expected that there will be three broad groups of variables which will have a possible impact on firm survival; firm-specific, industry-specific and macroeconomic. The first firm-specific variable to be considered is the initial ownership status of the firm and, in particular, whether the firm is locally-owned, UK-owned or foreign-owned. Our prior expectation is that foreign-owned firms are likely to survive longer than the other types, due to the financial backing which is likely to be provided by a foreign-owned parent setting up a new establishment in the UK. We expect this relationship to be stronger for SMEs than for micro-enterprises, since setting up a new establishment with ten or more employees indicates a greater level of commitment on the part of the foreign parent.

Many previous studies have suggested that there is a positive relationship between plant size and survival (see, for example, Audretsch and Mahmood (1995), McCloughan and Stone (1998), Disney et al. (2003), Perez et al. (2004) and Persson (2005)). The main explanation put forward for this relationship relates to the view that larger firms are more likely to have levels of output close 
to the minimum efficient scale (MES), ceteris paribus, and thus smaller firms have an inherent size disadvantage. While this may be true for SMEs, it is questionable whether this is the case for micro-enterprises. For very small firms, increases in size may have little impact in terms of moving towards the MES, but may well lead to extra burdens in terms of having to generate revenue to maintain the firm. As such, the expected relationship between the duration of microenterprises and plant size is negative. Finally, a positive relationship is expected between the level of grants provided to firms and firm survival. Clearly, grants provide a financial cushion which either lower set-up costs or reduce running costs.

Industry-specific variables have been widely examined in previous work in this area. The degree of competition is expected to have an impact on firm survival, with the concentration ratio being used as a proxy in several studies. The general argument put forward is that increased concentration in the industry will make the environment more difficult for new entrants, leading to greater risk of failure. However, while McCloughan and Stone (1998) and Baldwin and Rafiquzzaman (1995) find a significant relationship between concentration and firm duration, Wagner (1994) finds no such relationship for German manufacturing. Wagner, arguing along the lines of Geroski (1991), suggests that local conditions, in particular, market niches, are more likely to be important to small entrants and, thus, suggests that there may well be no significant relationship between concentration and survival. Thus, previous literature is divided on the role of concentration in the survival of new firms. Examination of this role here will provide further insight into this issue. 
There are a number of sectoral variables which may be expected to impact on firm duration. Sectoral output growth rates and growth in sectoral value-added are both expected to have a positive impact on survival, since increases in these variables are expected to be associated with expanded market opportunities ${ }^{13}$. In contrast sectoral wage rate increases may be expected to have a negative impact on survival, because such an increase is associated with rising costs. Finally, there may well be differences in survival rates between different industries over and above those captured by the other industry-specific variables, as some industries decline, while others expand (see for example, McCloughan and Stone (1998), Taylor (1999), and Li and Hamblin (2003)). For this reason, industry dummy variables are included in the analysis.

Let us now consider macroeconomic variables. The unemployment rate is expected to be negatively related to survival for two reasons. First, unemployment can be considered to be a proxy for demand, with higher unemployment being associated with lower demand. Second, it is possible that high unemployment leads to an increase in the number of start-ups, particularly for very small firms. In this case setting up a firm may be seen as an alternative to employment and may be a choice of last resort. Clearly, if this is the case, then we might again expect higher unemployment in the first year of operation to lead to a greater chance of the firm dying, given that many of the start-ups are

\footnotetext{
${ }^{13}$ In practice, such variables are highly correlated, since they are measuring very similar activity. As a result they are not included jointly in the analysis which follows. The final estimation reports results for those that were found to be the most important empirically.
} 
undertaken by people less well suited or with fewer skills appropriate to running a business.

Audretsch and Mahmood (1995) argue that the real interest rate may be positively related to the likelihood of failure, with higher borrowing costs placing an additional financial burden upon the enterprise. However, their results do not support this view. They argue that their findings may be due to the fact that most new firms do not rely on external capital. It is, of course, possible that there may be differences in terms of how micro enterprises and SMEs respond to changes in interest rates. By analysing this issue we provide further insights into the impact of this variable. The exchange rate variable which has been excluded from many previous studies could well be important for survival, particularly for firms that are more likely to face competition from abroad and to be involved with imports and exports. In general, it is to be expected that increases in the real effective exchange rate will have an adverse affect on firm survival, since such a change implies a worsening of the competitive position relative to overseas competitors. Clearly then, there are strong grounds for believing that firm-specific, industryspecific and macroeconomic variables may impact on firm survival. Furthermore, it is to be expected that such variables will impact differentially on microenterprises and SMEs. We now proceed to investigate these relationships.

\section{RESULTS}

Table 2 shows the results of the final versions of the model that were estimated for micro-enterprises and SMEs. The columns in Table 2 relate respectively to micro-enterprises and SMEs. A number of variables discussed in the previous 
section were not included in the final estimations, since they were found to be insignificant in relation to both samples. All other variables are significant to at least the $10 \%$ level, in the majority of cases the significance is $5 \%$ or higher. As can be seen from Table 2, the final specification demonstrates that firm-specific, industry-specific and macroeconomic variables have an impact on the survival of newly-established firms. Furthermore, it is evident from the results presented that there are substantial differences in the factors determining the survival of micro-enterprises compared with that of SMEs.

\section{TABLE 2 HERE}

Before considering the variables and how they impact on firm survival, it is instructive to examine the estimated hazard functions and to note the estimated value of $\rho$, the shape parameter, in each estimation. Figures 1a and $2 \mathrm{a}$ show the final estimated hazard functions for micro-enterprises and SMEs respectively. For both types of firms the figures show clear evidence of positive duration dependence, followed by negative duration dependence. This is borne out by examining the estimated value of $\rho$ in Table 2, which is shown to be approximately equal to 1.6 for both micro-enterprises and SMEs. This is statistically in excess of 1 and confirms that there is evidence of positive duration dependence followed by negative duration dependence ${ }^{14}$. The nature of duration dependence has received little attention in previous studies. This is surprising

\footnotetext{
${ }^{14}$ The standard errors reported in Table 2 imply 95\% confidence intervals of 1.4264 to 1.7694 for micro-enterprises and 1.3825 to 1.8525 for SMEs.
} 
given that it has important implications for policies designed to assist firm survival (for a notable exception see Mahmood (2000), who also reports that new firm hazard rates follow an inverted U pattern). The analysis here suggests that for both micro-enterprises and SMEs there is an increased likelihood of death in each subsequent period during the early years of establishment, but that there is then a turning point such that firms which survive beyond this point are then less likely to die in each subsequent period. The precise turning point, tp, can be determined using the following:

$$
t p=\left[\frac{(\rho-1)}{\lambda^{\rho}}\right]^{1 / \rho}
$$

Using the estimated values of $\lambda$ and $\rho$, the turning point for micro-enterprises is found to be 8.94 , while that for SMEs is 7.89 . Thus, it appears that negative duration dependence takes roughly a year longer to achieve for micro-enterprises than for SMEs. Nonetheless, for both firm types the period before negative duration dependence is relatively long. This suggests that policies designed to assist firm survival should not - as is typically the case - concentrate only on the first few years of a firm's existence. Figures 1a and 2a show the estimated conditional hazard functions for the two enterprise types. These present the probabilities of death at point $t$ conditional upon the firm surviving to the previous point in time. It can be seen that while the turning point for micro enterprises is later than for SMEs, the conditional probability of failure for micro enterprises is always lower than for SMEs. This lower probability of early death for micro-enterprises is also revealed by the estimated survival functions (Figures 
$1 \mathrm{~b}$ and $2 \mathrm{~b}$ ) which show that the approximate proportions of micro-enterprises and SMEs surviving after 10 years are $60 \%$ and $50 \%$ respectively.

\section{FIGURE 1A HERE \\ FIGURE 1B HERE \\ FIGURE 2A HERE}

FIGURE 2B HERE

Let us now consider the impact on duration of firm-specific variables. The results in relation to plant size are of considerable interest, particularly given that this has been a variable that has received much attention in the literature. The results presented here for SMEs are consistent with previous studies in that they provide evidence of a positive relationship between plant size and firm survival. In contrast, very small firms (those with total employment of 9 or less) are less likely to survive as start-up plant size increases. The findings offer strong evidence of differences in duration behaviour for the two sub-groups of firms. There thus appears to be a threshold level below which increased plant size is a burden on firms, suggesting that previous studies, which aggregated microenterprises with SMEs may have overlooked an important issue.

For both micro-enterprises and SMEs the initial ownership status of the firm was not found to have a significant impact on survival, ${ }^{15}$ this is consistent with the

\footnotetext{
${ }^{15}$ With respect to micro-enterprises the results are, perhaps, not surprising, given that only $6 \%$ were UK owned and that just $2 \%$ were initially under foreign ownership.
} 
results of Matta and Portugal (2002) who compared Portuguese domestic and foreign firms. They found that, after controlling for a limited number of firm and industry characteristics, there were no significant differences in the failure probabilities of the two firm types. Interestingly, our results suggest that foreign owned plants are more likely to survive, but, that this is due to their relatively larger size at establishment rather than their ownership status ${ }^{16}$.

It is clearly possible that the difference in results between micro-enterprises and SMEs is reflecting differences in ownership, rather than size at establishment. To investigate this, and to test the robustness of the results presented in Table 2, two additional regressions were estimated. These equations were estimated using only local observations, hence removing the issue of interactions between size and ownership, and are reported in Table $3^{17}$. Within this local sub-sample the same size effects are observed as in the entire sample, namely a negative relationship between size at establishment and survival for micro-enterprises and a positive one for $\mathrm{SMEs}^{18}$. The other parameter estimates within these regressions also exhibit identically signed coefficients to those within Table 2,

\footnotetext{
${ }^{16}$ This stands in contrast to the results of Gorg and Strobl (2003) who suggest that multinational plants are more 'footloose' than locally owned plants after controlling for plant- and industryspecific characteristics.

${ }^{17}$ Equivalent estimations were not feasible for non-local enterprises due to an insufficient number of observations.

${ }^{18}$ It should be noted that the size effect for SMEs was significant at only the $14 \%$ level. This may be due to the lack of 'large' SMEs within the local sub sample. The average size of the local SME was 21 employees, this compares to 31 for a UK owned SME and 38 for a foreign owned SME.
} 
with the exception of the change in exchange rate variable (which also relates to a different period in this second set of regressions) and also some differences in the industry dummies which are thought to reflect the make-up of plants by industry within the sub-sample.

\section{TABLE 3 HERE}

Returning to the main results in Table 2, there was no evidence that the provision of grants to newly-established firms has an impact on either firm type. Finally, in relation to firm-specific variables, it is worth noting that the specific location within the Wearside sub-region did not impact on firm duration ${ }^{19}$. This may appear at first sight to be somewhat surprising given the contrasting characteristics of Sunderland and Washington. The former has, over the period of analysis, shed a very substantial number of jobs and faced severe problems following the decline of traditional industries. In contrast Washington, as a new town, not only had a Development Corporation during some of the period analysed, but also benefited from better transport links and other infrastructure advantages. While old industries ${ }^{20}$ based in Sunderland were adversely affected during the 1970s and 1980s, the results suggest that there was not a significantly higher failure rate among newly-established manufacturing firms in Sunderland compared to their counterparts in other areas. This could be due, in part, to the

\footnotetext{
${ }^{19}$ In the interests of brevity, the results for the estimations including the location dummies are not reported. Inclusion of these dummies did not change the overall pattern of results. Results available on request.

${ }^{20}$ Established prior to our sample.
} 
fact that at the same time as the old industries were in decline in Sunderland, there was substantial investment in improving its infrastructure from the early 1980s, in particular via the activities of the Tyne \& Wear Urban Development Corporation.

To summarise thus far: it is clear that, as far as firm-specific variables are concerned increased plant size has a negative impact on the survival of microenterprises, but a positive impact on the survival of SMEs. Ownership variables, location and the receipt of grants do not have a significant influence on survival chances.

Turning to industry-specific factors, the sectoral growth rate, over the first three years after establishment of operations, was found to be of importance. The coefficient is of the expected sign, in that higher sectoral growth in the first few years of operations is associated with longer survival. This was found to be highly significant for both enterprise types, broadly in line with the findings, for the USA, of Audretsch and Mahmood (1995). It is particularly noteworthy that the coefficients for the concentration ratio were not significant. While some previous studies have found the concentration ratio at the date of establishment to be significant, the results presented here are consistent with those for German manufacturing presented in Wagner (1994). As Wagner argues, economy-wide industry-specific indicators are unlikely to be a good proxy for influences of competition and 'the lack of explanatory power of industry characteristics in the survival models is not surprising at all'. (1994, p147). 
The industry dummy variables clearly show that there are some significant differences across industries. For SMEs there is clear evidence of a negative effect associated with the textile industry and a positive effect in the rubber and plastics industry. For micro-enterprises there is a negative effect in the furniture industry and a positive effect in the miscellaneous manufacturing sector. Thus, in relation to industry-specific variables, there is clear evidence of differences across industries, but little relating to other industry-specific influences on firm survival.

Finally, we turn to macroeconomic variables. Three interest rate variables were included in the final estimations: the real short-term interest rate in the year in which the firm was established, the change in the short-term interest rate from the first to second year and the change in the real interest rate from the second to third year ${ }^{21}$. The real interest rate at establishment was significant for both micro firms and SMEs. While the micro-enterprise coefficient has the expected negative sign, the effect is positive for SMEs. There are various possible explanations for this: (1) higher interest rates are typically associated with times of high aggregate demand, and this positive effect is dominating the negative interest rate effect; (2) it is conceivable that this coefficient is picking up a screening effect, where more marginal SMEs are less likely to be established when interest rates are high due to higher opportunity costs of capital and credit rationing effects; hence high interest rates (at start-up) creates a cohort of SMEs

\footnotetext{
${ }^{21}$ Long-term interest rates were also included, but were found to have an insignificant impact. In addition, changes in the real short-term interest rate in other years were also examined, but also found to have no significant effect.
} 
with lower than otherwise probabilities of failure. Changes in the interest rate from the first to second and second to third year were found to be significant for micro-enterprises. Again the interest rate effects had the anticipated sign. The difference between the impact on micro-enterprises and SMEs is in line with expectations. Thus the results presented here suggest that low and stable interest rates are important in helping micro-enterprises to survive. The final variables found to be significant relate to changes in the exchange rate. However, this is only significant for micro-enterprises. The change in the real effective exchange rate, from the second to the third year was found to be significant and to have the expected sign. The unemployment rate, either that for the region, or the UK as a whole, was found to be an insignificant variable for both enterprise types ${ }^{22}$. To summarise: macroeconomic variables do have an impact on both enterprise types, but the effects are more complex for micro-enterprises than for SMEs.

\section{CONCLUSION}

This paper has analysed firm survival for newly-established firms in the NorthEast region of England, using a unique data set of 781 firms. This study is distinguished from previous work in that it estimates hazard functions separately for micro-enterprises and SMEs. This division of the data was undertaken because there are strong grounds for believing that economic factors will impact

\footnotetext{
${ }^{22}$ In addition, the model was estimated including a range of time-related variables to account for possible structural breaks or changes not taken into account by the time varying macroeconomic variables. Specifically, linear and quadratic time trends were included, as were a number of time related dummy variables. All such variables were insignificant and the results were qualitatively very similar to those reported in the tables. Results available on request.
} 
differentially on the two firm types. The distinction between the two types of firms is found to be important, with variables having a substantially differential impact on micro-enterprises and SMEs. Further, the results presented here demonstrate that firm-specific, macroeconomic and industry-specific variables have important implications for firm survival.

In line with prior expectations, increases in initial plant size are seen to have a positive impact on the survival of SMEs. However, increases in plant size were found to impact negatively on micro-enterprise durations. In contrast to the findings of some research, ownership of the enterprise was not identified as a significant firm-specific variable. Our results suggest that the longer survival durations associated with foreign ownership are a function of larger sizes at establishment rather than ownership per se.

As far as macroeconomic variables are concerned, higher rates of unemployment were not associated with survival chances. This finding would appear to be incompatible with the view that micro-enterprises are often set up as an alternative of last resort for individuals facing unemployment. The key macroeconomic variables that emerged from the study were interest rates and exchange rates. For micro-enterprises, low interest rates at establishment enhance firm survival, while beyond the first year of operation, increases in the real interest and exchange rates impact negatively on their survival probabilities.

Both micro-enterprises and SMEs exhibited clear evidence of initial positive duration dependence, followed by negative duration dependence - enterprises 
displayed increased probabilities of death for the first eight to nine years. These findings are particularly interesting in the context of current debates in the UK concerning support for small firms. First of all, they suggest that policies to assist survival should concentrate on more than just the first few years. After all, the probability of death rises for almost the first decade of operations. Secondly, there is the possibility that encouraging the rapid expansion of micro-enterprises as a mechanism for economic growth and development, may inadvertently increase the probability of failure for these business. 
The authors are grateful to Tony Antoniou, Peter Johnson, Simon Parker, Martin Robson, David Storey, Colin Wren and an anonymous referee for helpful comments on earlier drafts. The authors are particularly grateful to Paul Braidford for extensive help with the data for this paper. The usual disclaimer applies 


\section{References}

Agarwal, R. (1998). 'Small firm survival and technological activity', Small Business Economic,s 11, pp. 215-24

Arrighetti, A. and Vivarelli, M. (1999). 'The rôle of innovation in the postentry performance of new small firms: Evidence from Italy', Southern Economic Journal, 65, pp. 927-39

Audretsch, D.B. (1995). 'The propensity to exit and innovation', Review of Industrial Organization, 10, pp. 589-605

Audretsch, D.B. and Mahmood, T. (1994). 'Firm selection and industry evolution: The post-entry performance of new firms', Journal of Evolutionary Economics, 4, pp. 243-60

Audretsch, D.B. and Mahmood, T. (1995). 'New-firm survival: New results using a hazard function', Review of Economics and Statistics, 77, pp. 97-103

Audretsch, D.B., Santarelli, E. and Vivarelli, M. (1999). 'Start-up size and industrial dynamics: some evidence from Italian manufacturing', International Journal of Industrial Organization, 17, pp. 965-83

Baldwin, J.R. and Rafiquzzaman, M. (1995). 'Selection versus evolutionary adaptation: Learning and post-entry performance', International Journal of Industrial Organization, 13, pp. 501-22

Bank of England (1994-2001) Finance for Small Firms, Nos. 1 to 8, Bank of England, London, UK

Deakins, D. and Freel, M. (2006) Entrepreneurship and Small Firms, $4^{\text {th }}$ Edition, McGrawHill, Maidenhead, UK 
Disney, R., Haskel, J. and Heden, Y. (2003). 'Entry, Exit and Establishment Survival in UK Manufacturing', Journal of Industrial Economics, 51, pp. 91122.

Dunne, P. and Hughes, A. (1992). 'Age, size, growth and survival: UK companies in the 1980s', Journal of Industrial Economics, 42, pp. 115-40

Dunne, T., Roberts, M.J. and Samuelson, L. (1988). 'Patterns of firm entry and exit in US manufacturing industries', Rand Journal of Economics, 104, pp. $671-98$

Fotopoulos, G. and Louri, H. (2000) 'Location and Survival of New Entry', Small Business Economics, 14, pp. 311-21

Gorg, H. and Strobl, E. (2003) 'Multinational Companies, Technology Spillovers and Plant Survival' The Scandinavian Journal of Economics, 105, pp. 581-95

Geroski, P.A. (1991). Market Dynamics and Entry, Blackwell, Oxford

Li, X. and Hamblin, D. J. (2003) 'The Impact of Performance and Practice Factors on UK Manufacturing Companies' Survival' International Journal of Production Research, 41, pp. 963-79

Mahmood, T. (2000) 'Survival of Newly Founded Businesses: A Log-Logistic Model Approach' Small Business Economics, 14, pp. 223-37

Mata, J. and Audretsch, D.B. (eds.) (1995). 'The Post-Entry Performance of Firms', special issue of International Journal of Industrial Organization, 13, pp. $413-614$

Mata, J. and Portugal, P. (1994). 'Life duration of new firms', Journal of Industrial Economics, 42, pp. 227-45 
Mata, J. and Portugal, P. (2002). 'The Survival of New Domestic and Foreign Firms’, Strategic Management Journal, 23, pp. 323-43

McCloughan, P. and Stone, I. (1998). 'Life duration of foreign multinational subsidiaries: Evidence from UK northern manufacturing industry 1970-93', International Journal of Industrial Organization, 16, pp. 719-48

Perez, S. E., Llopis, A. S. and Llopis, J. A. S. (2004) 'Determinants of Survival of Spanish Manufacturing Firms' Review of Industrial Organization, 25, pp. $251-73$

Person, H. (2004) 'The Survival and Growth of New Establishments in Sweden, 1987-1995' Small Business Economics, 23, pp. 423-40

Reid, G.C. (1991). 'Staying in Business', International Journal of Industrial Organization, 9 , pp. 545-56

Segarra, A. and Callejon, M. (2002) 'New Firms' Survival and Market Turbulance: New Evidence from Spain' Review of Industrial Organisation, 20, pp. $1-14$

Stone, I. and Peck, F. (1996). 'The foreign-owned manufacturing sector in UK peripheral regions, 1978-1993: restructuring and comparative performance', Regional Studies, 30, pp. 55-68

Stone, I., Braidford, P. and Allinson, G. (2004) 'Small Business Succession: An International Literature Review', Annex to Small Business Service, Passing the Baton - Encouraging Successful Business Transfers. Department of Trade and Industry, HMSO London

Stone, I. and Stevens, I. (1986) 'Small Firms and Employment Potential on Wearside' Report for the EEC/Sunderland Borough Council 
Storey, D.J. (1990). 'Evaluation of policies and measures to create local employment', Urban Studies 27, pp. 669-84

Taylor, M.P. (1999). 'Survival of the Fittest? An Analysis of Self-Employment Duration in Britain', Economic Journal 109, pp.140-55

Wagner, J. (1994). 'The post-entry performance of new small firms in German manufacturing industries', Journal of Industrial Economics 42, pp. 141-54 
Table 1: Number of firms established by start-up date and status in 2002

\begin{tabular}{|l|r|r|r|}
\hline Sub period & \multicolumn{2}{|c|}{$\begin{array}{c}\text { Number of } \\
\text { firms }\end{array}$} & \multicolumn{2}{|c|}{ Status in 2002 } \\
\cline { 3 - 4 } & established & Number alive & $\begin{array}{c}\text { \% Alive } \\
\text { (Truncated) }\end{array}$ \\
\hline $1973-80$ & 236 & 55 & 23.3 \\
\hline $1981-85$ & 299 & 125 & 41.8 \\
\hline $1986-90$ & 131 & 58 & 44.3 \\
\hline $1991-95$ & 70 & 37 & 52.9 \\
\hline $1996-2001$ & 45 & 43 & 95.6 \\
\hline Total & 781 & 318 & 40.7 \\
\hline
\end{tabular}


Table 2: Log-logistic hazard model estimates of the determinants of firm survival for micro-enterprises and SMEs

\author{
Variable \\ Constant \\ Firms specific variables: \\ Plant Size \\ Macroeconomic variables: \\ Real interest rate - year 1 \\ second year \\ third year \\ third year

\section{Industry specific variables:} \\ elsewhere classified \\ Manufacture of furniture \\ Number of observations \\ $\rho$ \\ (se) \\ $\lambda$ \\ (se) \\ Log-likelihood
}

Micro-

enterprises

2.8391

${ }^{* * *} 0.1234$

SMES

2.0621

${ }^{* * *} 0.1439$

$-0.0670$

${ }^{\star * *} 0.0240$

0.0166

Change in real interest rate - first year to

$-0.0405$

${ }^{* * *} 0.00577$

${ }^{* *} 0.0185$

0.0395

${ }^{*} 0.0184$

$-0.0308$

${ }^{*} 0.0170$

Change in real interest rate - second year to

$-0.0323$

${ }^{\star *} 0.0166$

Change in exchange rate- second year to

0.0154

${ }^{*} 0.00739$

Sectoral growth rate - years 1 to $3 \quad 1.4746$

1.9422

${ }^{* \star *} 0.4689$

***0.7182

Manufacture of wearing apparel

$-1.4565$

Manufacture of rubber and plastic products

${ }^{* * *} 0.2294$

1.0958

${ }^{* * *} 0.4156$

Manufacture of machinery and equipment not

0.4171

${ }^{\star * \star} 0.1476$

$-0.3805$

${ }^{* * *} 0.1300$

0.6258

${ }^{* * *} 0.0343$

0.6182

${ }^{* * \star} 0.0458$

547

232

1.5979

0.0875

1.6175

0.0811

0.1199

0.00404

0.0953

$-637.0381$

0.0079

$-262.2127$ 
Table 3: Log-logistic hazard model estimates of the determinants of locally owned firm survival for micro-enterprises and SMEs

\begin{tabular}{|c|c|c|}
\hline Variable & $\begin{array}{l}\text { Local } \\
\text { Micro- } \\
\text { enterprises }\end{array}$ & Local SMEs \\
\hline Constant & $\begin{array}{r}2.7900 \\
* \star * 0.0252\end{array}$ & $\begin{array}{r}2.2034 \\
* \star * 0.0152\end{array}$ \\
\hline \multicolumn{3}{|l|}{ Firms specific variables: } \\
\hline Plant Size & $\begin{array}{l}-0.0678 \\
{ }^{* \star} 0.0252\end{array}$ & $\begin{array}{l}0.0106 \\
0.00713\end{array}$ \\
\hline \multicolumn{3}{|l|}{ Macroeconomic variables: } \\
\hline Real interest rate - year 1 & $\begin{array}{l}-0.0461 \\
* \star 0.0204\end{array}$ & $\begin{array}{r}0.0475 \\
{ }^{*} 0.0248\end{array}$ \\
\hline $\begin{array}{l}\text { Change in real interest rate - first year to } \\
\text { second year }\end{array}$ & $\begin{array}{l}-0.0447 \\
{ }^{*} 0.0195\end{array}$ & \\
\hline $\begin{array}{l}\text { Change in real interest rate - second year to } \\
\text { third year }\end{array}$ & $\begin{array}{r}-0.0323 \\
{ }^{*} 0.0179\end{array}$ & \\
\hline $\begin{array}{l}\text { Change in exchange rate- first year to seconc } \\
\text { year }\end{array}$ & $\begin{array}{l}-0.0135 \\
{ }^{* *} 0.00651\end{array}$ & \\
\hline \multicolumn{3}{|l|}{ Industry specific variables: } \\
\hline Sectoral growth rate - years 1 to 3 & $\begin{array}{l}1.0268 \\
{ }^{*} 0.5300\end{array}$ & $\begin{array}{r}1.8033 \\
{ }_{*}^{*} 0.8034\end{array}$ \\
\hline Manufacture of wearing apparel & & $\begin{array}{l}-0.6918 \\
* * \star 0.3853\end{array}$ \\
\hline Manufacture of rubber and plastic products & $\begin{array}{l}0.4438 \\
{ }^{*} 0.2136\end{array}$ & \\
\hline $\begin{array}{l}\text { Manufacture of machinery and equipment not } \\
\text { elsewhere classified }\end{array}$ & $\begin{array}{l}0.3764 \\
{ }_{*}^{*} 0.1589\end{array}$ & \\
\hline Manufacture of furniture & $\begin{array}{l}-0.3725 \\
* * * 0.1342\end{array}$ & \\
\hline Manufacture of fabricated metal products & & $\begin{array}{l}-1.4606 \\
* * \star 0.2557\end{array}$ \\
\hline Sigma & $\begin{array}{r}0.6309 \\
{ }^{* \star} 0.0363\end{array}$ & $\begin{array}{r}0.5758 \\
* \star 0 \\
* 0.0485\end{array}$ \\
\hline Number of observations & 502 & 160 \\
\hline $\begin{array}{l}\rho \\
(\mathrm{se})\end{array}$ & $\begin{array}{r}1.5849 \\
0.0913\end{array}$ & $\begin{array}{r}0.1165 \\
0.0105\end{array}$ \\
\hline$\lambda$ & 0.0805 & 1.7366 \\
\hline (se) & 0.0042 & 0.1463 \\
\hline Log-likelihood & -584.7601 & -183.5980 \\
\hline
\end{tabular}


Figure 1a: Estimated Hazard Function for Micro-Enterprises

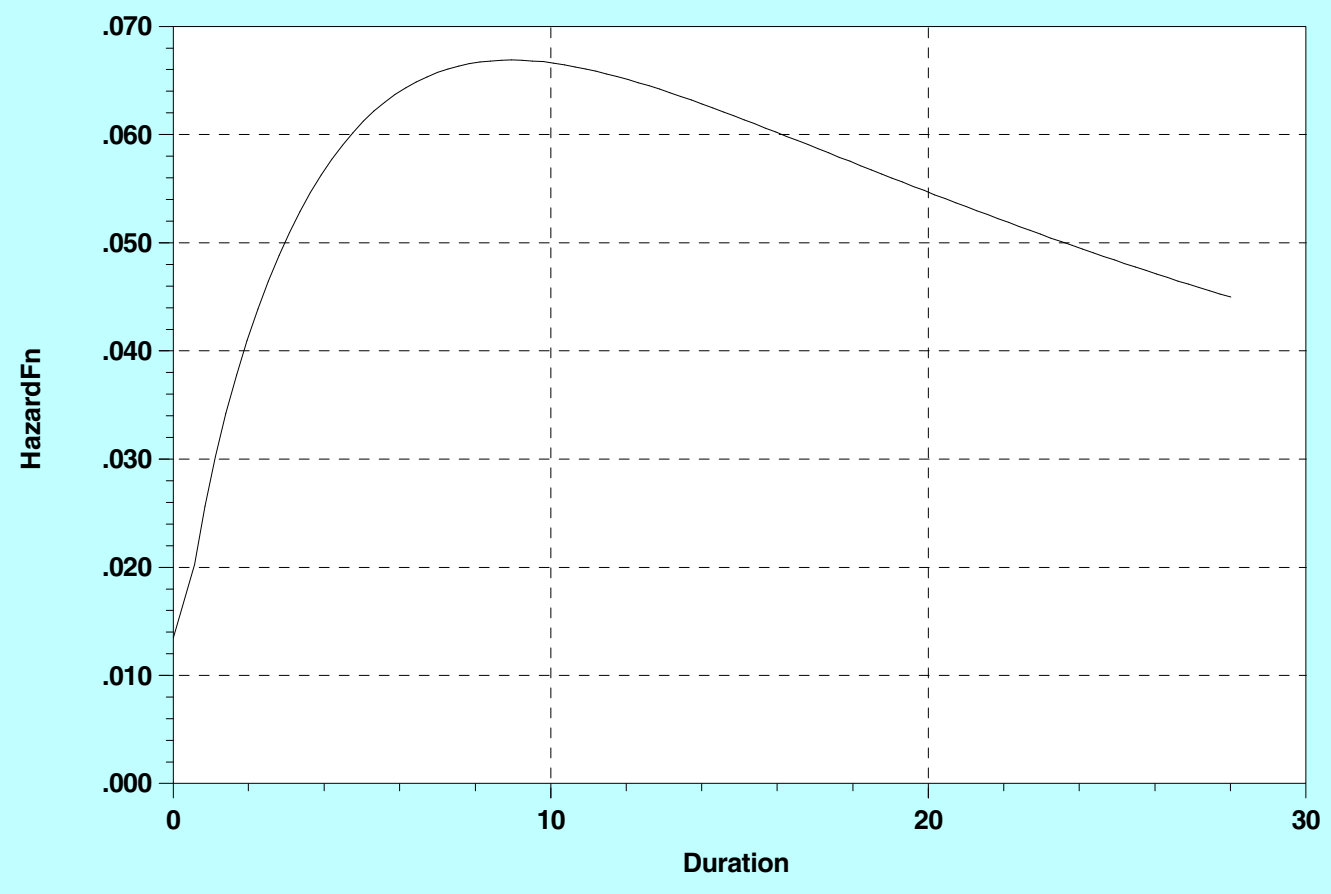

Estimated Hazard Function for LDUR 
Figure 1b: Estimated Survival Function for Micro-Enterprises

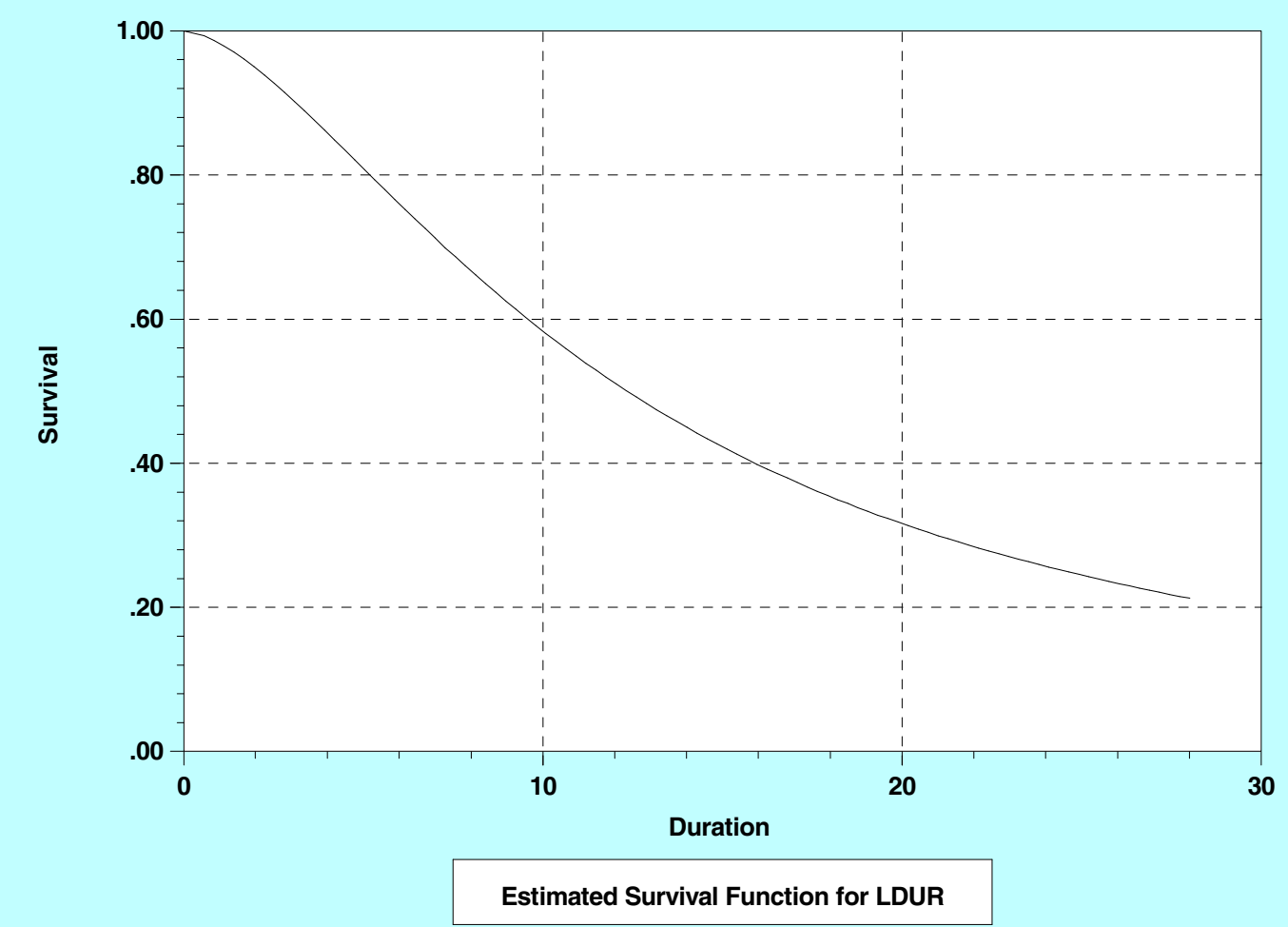


Figure 2a: Estimated Hazard Function for SMEs

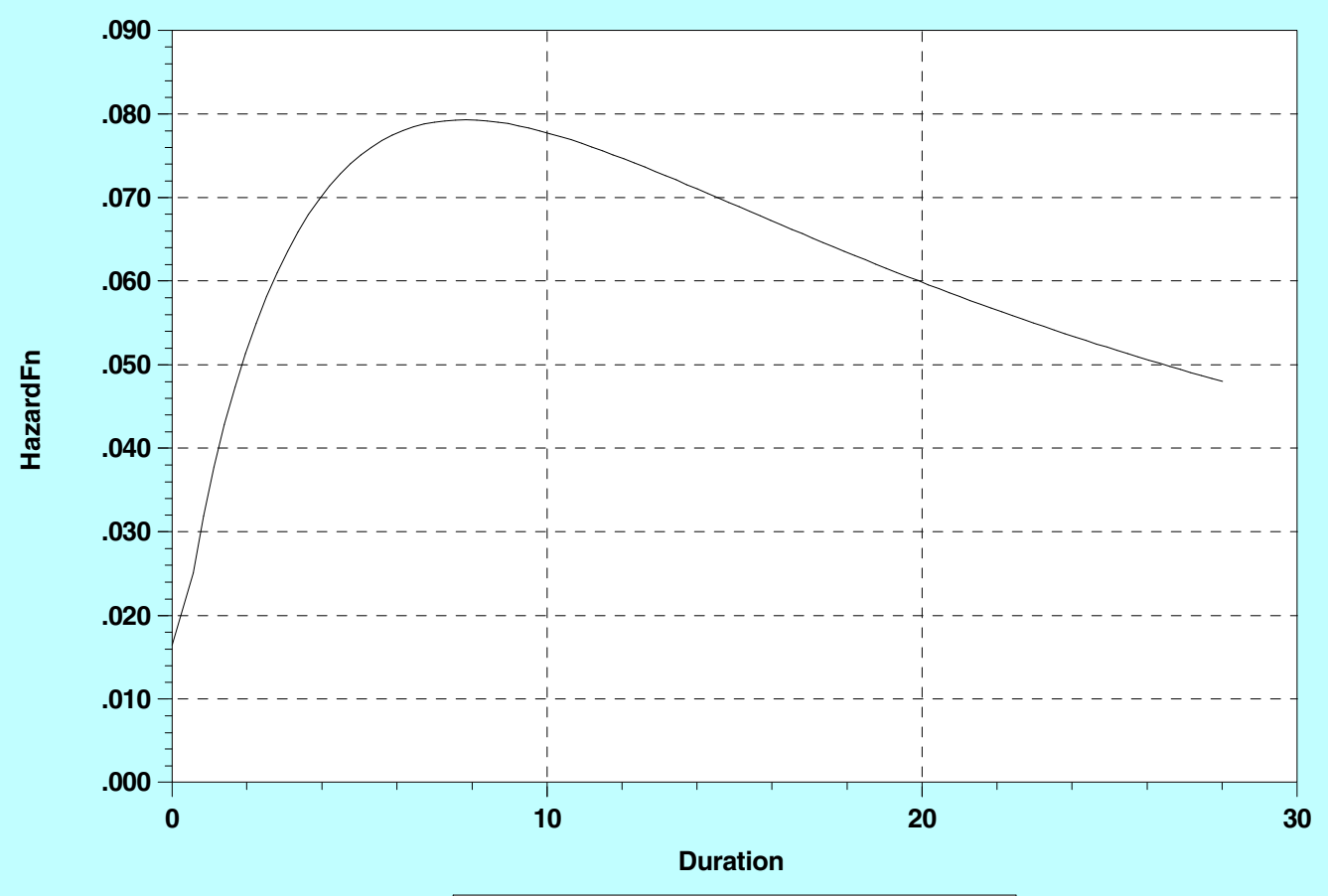

Estimated Hazard Function for LDUR 
Figure 2b: Estimated Survival Function for SMEs

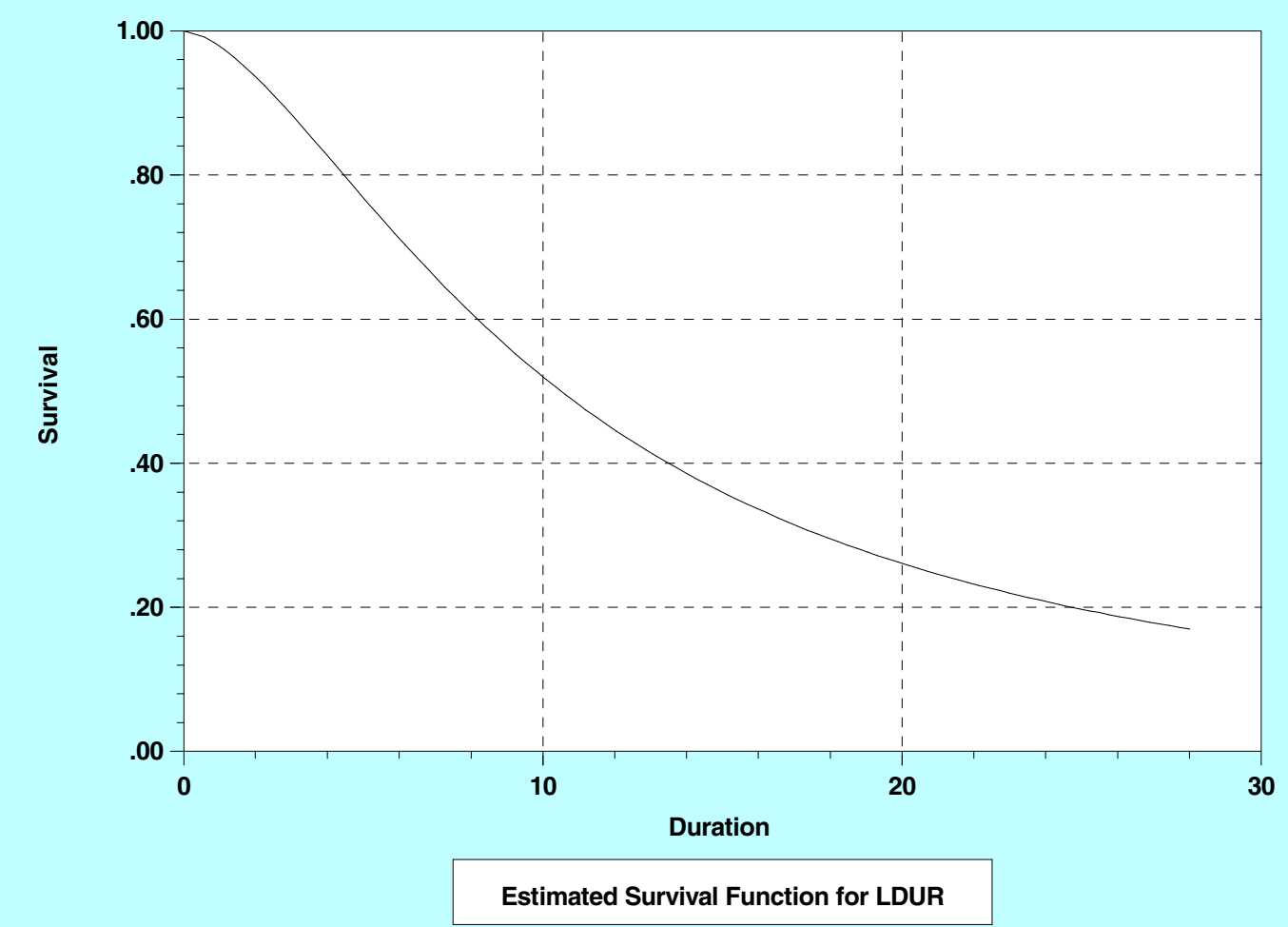




\title{
AN ANALYSIS OF NEW FIRM SURVIVAL USING A HAZARD \\ FUNCTION
}

by

Phil Holmes, Andrew Hunt and Ian Stone

\begin{abstract}
$\underline{\text { Abstract }}$
A unique dataset is used to provide a detailed examination of the survival of newly-established manufacturing firms in north-east England. Using data on 781 firms established between 1973 and 2001, log-logistic hazard models are estimated separately for (i) micro-enterprises and (ii) small and medium establishments (SMEs). Both micro-enterprises and SMEs show clear evidence of positive duration dependence, followed by negative duration dependence. We find the two firm types are differentially affected by firm-specific and macroeconomic variables. Increases in initial plant size impact negatively on micro-enterprise survival and positively on SME survival.
\end{abstract}

Keywords: new firm survival, hazard models, micro-enterprises.

Word count: 6700 words.

JEL classification: C41, L10.

Running title: Hazard estimations of new firm survival.

Corresponding author: Andrew Hunt, School of Economics, Finance and Business. University of Durham, Mill Hill Lane, Durham, DH1 3HY, UNITED KINGDOM, Tel: 0191334 5424, Fax: 01913345201.

Andrew Hunt is a Research Associate in the School of Economics, Finance and Business at the University of Durham

Professor Ian Stone is a Professorial Fellow in the School of Economics, Finance and Business at the University of Durham 


\section{INTRODUCTION}

In the UK since the early 1980s the birth of new firms has been seen as a major means by which unemployment might be constrained or reduced. As such, a panoply of government initiatives designed to promote small firm start-ups and (to a lesser extent) growth has been introduced (for a discussion of some of the key policies see Storey (1990)). Implicit in these policies has been the assumption that, once established, firms continue to make a contribution to the economy. While firm entry is clearly of importance, arguably duration can be considered to be of greater significance in terms of meeting long-term policy objectives related to employment and the growth of the economy. The current concern to develop policies to help improve the rates of business succession (when the owner wishes to exit) reflects this concern (Stone, et al. 2004). Over the past two decades considerable work has been undertaken on the post-entry performance of new firms (see, for example, Mata and Portugal (2002), Arrighetti and Vivarelli (1999), Audretsch and Mahmood (1995), and Mata and Portugal (1994) $)^{1}$. However, while much attention has been given to factors affecting the birth and death of firms in the UK, and to the duration of firm

\footnotetext{
${ }^{1}$ In addition to these studies there have been others examining post-entry performance and new firm entry, see, for example, Agarwal (1998), Audretsch (1995), Audretsch and Mahmood (1994), Audretsch, Santarelli and Vivarelli (1999), Dunne, Roberts and Samuelson (1988), Fotopoulos and Louri (2000) Geroski (1991), Mahmood (2000), Pérez, Llopis and Llopis (2004), Persson (2004), Segarra and Callejón (2002) and the special edition of the International Journal of Industrial Organisation, edited by Mata and Audretsch (1995).
} 
survival in other countries, to date there has been a paucity of work directly investigating new firm duration in the $\mathrm{UK}^{2}$.

Furthermore, in examining the firm duration issue, all previous studies have undertaken analysis for new firms as a group. This may have resulted in some of the underlying relationships being masked. Therefore, in this study, the approach taken is to use sub-samples based on the characteristics that the literature suggests may be relevant to survival, for example, local vs. non-local ownership and micro as opposed to larger sized firms (SMEs). Interestingly, the result to emerge is that thare are considerable differences between the factors affecting the survival of micro-enterprises and those affecting small and medium

\footnotetext{
2 Dunne and Hughes (1992) examine firm survival for UK companies and Reid (1991) analyses factors helping small entrepreneurial firms to stay in business using a sample of firms in Scotland, but in neither paper is a longitudinal dataset available and both use a sample which does not relate specifically to new firms. In contrast, Taylor (1999) investigates the duration of self-employment spells in Britain using the British Household Panel Survey. However, this involves an analysis of duration at the level of the individual, rather than the firm. Thus the current work can be viewed as being complementary to Taylor's study. McCloughan and Stone (1998) examine survival in the context of the UK, but their work relates to foreign multinational subsidiaries and uses a much smaller sample than is used in the current study. In a comprehensive study, Disney et al (2003) examine entry, exit and survival of UK manufacturing firms. However, this study only relates to establishments with 100 or more employees, does not relate specifically to new firms and examines a relatively short time period (1986-1991) compared to the current study. Li and Hamblin (2003) investigate the effects of manufacturing performance on the survival of UK manufacturing companies' using a relatively small sample of 156 UK wide observations, collected during the 1980s and 1997.
} 
establishments (SMEs) $)^{3,4}$. In the light of this, previous studies may well have resulted in inappropriate policy conclusions being drawn.

This shortage of work on the UK is due primarily to the lack of suitable available datasets to investigate the issue. As Mata and Audretsch note, "in order to analyze the post-entry performance of firms, a large longitudinal database to track firms subsequent to their entry is needed." (1995, p416). To date, such a database has not been available for the UK. The current study utilises a unique, relatively large, database relating to manufacturing firms established in the Wearside area of England over the twenty-nine year period 1973-2001 compiled, over time, by one of the authors. This has been augmented with additional data from the Office of National Statistics. By using this dataset, augmented by other data, together with the hazard rate approach, we are able to analyse firm duration over a long period (1973-2002), and to identify the impact of firm-specific, industry-specific and macroeconomic variables on firm survival. In addition, given the size of the database used, we are able to analyse separately the factors determining the survival of (i) micro-enterprises and (ii) SMEs. Given that there

\footnotetext{
${ }^{3}$ We define micro-enterprises as establishments with total employment at the start-up date of nine or less and SMEs as establishments with total employment at the start-up date of ten or more. It should be noted that some of the establishments we term SMEs are not SMEs in the traditional sense as they are plants of larger enterprises located elsewhere (see section II below for further discussion). However, for convenience we use the terms firm, enterprise and establishment interchangeably in relation to the sample analysed.

${ }^{4}$ It is, of course, the case that a number of studies analyse the impact of firm or plant size on duration by including size as an independent variable (see, for example, Audretsch and Mahmood (1995), McCloughan and Stone (1998), Disney et al. (2003) and Li and Hamblin (2003)).
} 
are strong economic grounds for believing that these two types of enterprise will be affected differently by different variables, it is desirable to model their survival separately. As such, this paper makes an important contribution to our understanding of the post-entry performance of newly-established manufacturing firms in a UK region and provides important implications for government policy designed to promote the survival of new small firms.

While the sample used here relates to one sub-region of the UK only, nonetheless, the results have wider relevance. Industrial performance at either the national or regional level is crucially affected by the ability of newly-established firms and plants to survive and grow. New firms are one means by which a manufacturing economy adjusts its specialisation over time towards more competitive products and they are an important counterbalance to contraction and closure. Similarly, the renewal process can be achieved by the establishment (on green or brownfield sites) of new plants by externally-owned companies. The extent to which the new units thrive and develop impacts upon the components of change and thus the stock of producers over time ${ }^{5}$. Understanding the dynamics of growth at the regional level has attracted increasing attention over recent years. After decades of nationally-operated policies relating to industry, the UK has decentralised policy formulation and delivery through the network of Regional Development Agencies. Identifying the factors that influence firm survival within

\footnotetext{
${ }^{5}$ A regional illustration of the dynamic process relating to foreign direct investment is given in Stone and Peck (1996).
} 
an area that is typical of peripheral UK regions is thus a topic of considerable practical relevance.

To summarise the results, we find that there are considerable differences in the factors affecting the survival of micro-enterprises and SMEs. In particular, it is shown that initial plant size has a negative impact on the survival of microenterprises, but a positive impact on the survival of SMEs, while initial ownership status is not of importance for survival of either enterprise type. It is also shown that both types of enterprises are characterised by positive duration dependence followed by negative duration dependence. This calls into question the results of previous studies that have utilised hazard functions which assume duration dependence to be monotonically increasing or decreasing (e.g. the Weibull distribution).

The remainder of the paper is organised as follows: section II discusses methodological issues and the empirical design used in this study. In section III we set out the relationships to be examined in this paper between firm survival and economic variables. Results are presented and discussed in section IV and section V provides a summary and concluding remarks.

\section{METHODOLOGICAL ISSUES AND EMPIRICAL DESIGN}

In order to investigate factors affecting firm survival, it is necessary to examine data concerning the duration of the life of a firm. A major problem encountered when analysing duration data is that of censored data. In this study censored data refers to those firms which were still alive at the time when the data was last 
updated. To overcome the problems caused by censored data it is necessary to consider not only whether a firm will cease trading, but also the length of time the firm trades. This can be achieved by using a hazard rate approach. The hazard rate model of the duration of the life of a firm provides a statistical representation of the relation between the survival time of a firm and certain explanatory variables. The model is a natural one for working with data which has a longitudinal element, as it provides a method for dealing with censored data. The hazard rate approach involves modelling the conditional probability that a firm will cease trading over a specified period. The hazard rate can be thought of as the rate at which firms die after duration $t$, given that they are alive at least until time $\mathrm{t}$.

An important concept in considering the hazard function is duration dependence. If the hazard function for a particular distribution slopes upwards (downwards), then the distribution has positive (negative) duration dependence. Positive (negative) duration dependence implies that the likelihood of failure at time t, conditional on duration up to $t$, is increasing (decreasing) in $t$. Different parametric specifications of the hazard function display different duration dependence behaviour. Four widely used distributions in economics are the exponential which displays constant duration dependence, the Weibull for which the hazard function is monotonically increasing or decreasing (depending on the value of the relevant parameter), the log-normal and the log-logistic which can both display increasing duration dependence initially, followed by decreasing duration dependence. It is also possible that the log-logistic distribution will display only negative duration dependence. Which behaviour is displayed 
depends upon the estimated value of the shape parameter. A priori it is not obvious which distribution is most appropriate. In this study all four distributions were used and the log-logistic was chosen on the basis of the loglikelihood values. The results presented in the following section are based on this distribution ${ }^{6}$. With the log-logistic distribution the hazard function is given by:

$$
\lambda(t)=\lambda \rho(\lambda t)^{\rho-1} /\left[1+(\lambda t)^{\rho}\right]
$$

where $\lambda(t)$ is the hazard function and $\rho$ is a shape parameter. If $\rho>1$ then there is positive duration dependence followed by negative duration dependence. If $\rho=1$ then there is monotonic negative duration dependence. Explanatory variables (or 'covariates') can be included in the model by letting $\lambda$ be a function of a set of regressors:

$$
\lambda_{i}=e^{-\beta x_{i}}
$$

where $x_{i}$ are variables which affect survival and the parameters are given by $\beta$. Thus, the model is formulated in terms of the effects of explanatory variables on the probability of the firm dying, the hazard function. The sign of the estimated coefficients indicates the direction of the effect of the variable on the hazard function, with a negative coefficient implying shorter durations (increased probability of death) and a positive coefficient longer durations.

\footnotetext{
${ }^{6}$ In addition, the Cox proportional hazard model was also utilised. The general pattern of results was similar across all specifications. Results from the other specifications are available on request.
} 
Previous studies of the survival of new firms have been constrained by the paucity of available data. In order to undertake detailed analysis of duration, it is necessary to have a sample of firms that is sufficiently large, covers a relatively long time period and is complete in terms of the timing of both births and deaths. In addition, in order to examine the impact of macroeconomic variables on firm survival, it is desirable for the sample to include firms with different start dates. The main database used in this study comprises a unique sample of 781 manufacturing firms in Wearside, North East England that were newlyestablished over the period 1973-2001 ${ }^{7}$. Of the 781 firms, 318 (40.7\%) were still in business ('alive') in 2002 (the end of the sample period), while 463 (59.3\%) had ceased trading ('dead'). Table 1 provides a summary of the number of firms splitting the sample into five year sub-periods by date of establishment (with the exception of the first period which is eight years). It also provides a breakdown by sub-period of those that were alive in 2002, and hence represent truncated observations. Two important empirical issues need to be discussed. First, there is a potential problem caused by heterogeneity of the data. For example, included within the sample are externally-owned sub-units of larger enterprises, while others are completely new start-ups. While this heterogeneity of the sample is potentially problematic, it is mitigated by sub-dividing the

\footnotetext{
${ }^{7}$ The vast majority of these newly-established firms consist of entirely new start-ups within the boundary of Wearside. A small number of the newly-established firms consist of recently formed local firms re-locating from outside the boundary for purposes (typically) of procuring more suitable premises; the remainder consist of externally-owned companies establishing new production facilities in the area via greenfield investment or by taking over facilities vacated by a firm which has gone into liquidation or moved out of the area.
} 
sample into micro-enterprises and SMEs and by the use of plant size and ownership status as independent variables. In addition, the construction of the sample has ensured that it does not contain 'dead ducks' (very short-life firms that by their nature have extremely little chance of survival $)^{8}$. Second, it is obvious from Table 1 that there was a large influx of firms in the period 1981-85, with many of these firms subsequently exiting. This raises the question of whether there is a cohort effect affecting this group of entrants. However, it should be noted that the failure rate for this group of firms is much lower than that of the firms established earlier (although obviously the latter group have had a longer time in which to fail) and similar to that for that group of firms established in the latter half of the 1980s. More importantly, differences in cohorts through time are taken into account by the inclusion of industry-specific and macroeconomic independent variables.

\section{TABLE 1 HERE}

The database allows the identification for each firm of the date of establishment, the date of closure (if dead), the initial ownership status of the firm (foreign, UK or local), plant size (as measured by the number of employees within the first two years of trading), the 4-digit standard industrial classification (SIC 1992) code for the firm, the total grants received (adjusted to 1990 prices) over the life of the

\footnotetext{
${ }^{8}$ New entrants have been identified using a variety of sources (e.g. local authority and private sector industrial property lists, industrial directories, etc.), verified by either telephone or postal contact at a later date. The data-gathering process is such that very short-life firms (i.e. those existing for just a few months) were excluded from the database.
} 
firm to 2002, and the location within the Wearside area (Washington New Town, the former coalfield zone of Houghton, Inner Sunderland, Outer Sunderland). This database information was augmented by data on macroeconomic and industry-specific variables. In particular, use was made of data on average annual short- and long-term real interest rates, average annual effective exchange rates, annual sectoral growth rates, annual sectoral employment growth rates, annual average sectoral wage rates, annual sectoral growth value-added in the UK, annual unemployment rate in the (Northern) Region and the UK, and the 3digit five-firm concentration ratio at the year of establishment ${ }^{9}$. It is argued that by utilising company-specific, industry-specific and macroeconomic variables data, it should be possible to identify the main factors affecting firm survival.

In estimating the hazard models, the data set is divided into two sub-samples on the basis of plant size at the establishment date. Models are estimated separately for those firms with total employment at the date of establishment of nine or less (micro-enterprises) and those with total employment of ten or more at the date of establishment (SMEs). Within the original dataset were a small number of 'larger' enterprises with over 100 employees at establishment, these were excluded on the grounds that their sizes were a-typical and there is no reliable method to ascertain if these enterprises were drawn from the same population as

\footnotetext{
${ }^{9}$ Details of the data used in the final estimations and the sources are provided in the Appendix at the end of the paper.
} 
the rest of the SME cohort ${ }^{10}$. This sub-division of the sample into micro and SME is undertaken to reflect the fact that the variables determining duration are likely to differ between micro-enterprises and SMEs ${ }^{11}$. While it might have been desirable to further sub-divide the SME group, this was not possible due to the sample size. The sub-division resulted in a sample of 549 for micro-enterprise firms (of which $41 \%$ were alive in 2002) and 232 SMEs (39\% alive in 2002).

\section{RELATIONSHIP BETWEEN FIRM SURVIVAL AND ECONOMIC} VARIABLES

The choice of covariates to be included in the analysis has been determined by prior expectations based on theory and previous empirical studies. As indicated above, it is expected that there will be three broad groups of variables which will have a possible impact on firm survival; firm-specific, industry-specific and macroeconomic. The first firm-specific variable to be considered is the initial ownership status of the firm and, in particular, whether the firm is locally-owned, UK-owned or foreign-owned. Our prior expectation is that foreign-owned firms are likely to survive longer than the other types, due to the financial backing

\footnotetext{
${ }^{10}$ The definitions used here are broadly consistent with those of the European Commission, which defines micro-enterprises as having between 0 and 9 employees and SMEs as having 10 - 499 employees.

${ }^{11}$ In the results reported below this is found to be the case. Indeed, when estimations were undertaken for the entire sample (micro-enterprises and SMEs together), a number of variables found to be significant below, were found to be insignificant, highlighting the importance of differentiating between the two types of firms.
} 
which is likely to be provided by a foreign-owned parent setting up a new establishment in the UK. We expect this relationship to be stronger for SMEs than for micro-enterprises, since setting up a new establishment with ten or more employees indicates a greater level of commitment on the part of the foreign parent.

Many previous studies have suggested that there is a positive relationship between plant size and survival (see, for example, Audretsch and Mahmood (1995), McCloughan and Stone (1998), Disney et al. (2003), Perez et al. (2004) and Persson (2005)). The main explanation put forward for this relationship relates to the view that larger firms are more likely to have levels of output close to the minimum efficient scale (MES), ceteris paribus, and thus smaller firms have an inherent size disadvantage. While this may be true for SMEs, it is questionable whether this is the case for micro-enterprises. For very small firms, increases in size may have little impact in terms of moving towards the MES, but may well lead to extra burdens in terms of having to generate revenue to maintain the firm. As such, the expected relationship between the duration of microenterprises and plant size is negative. Finally, a positive relationship is expected between the level of grants provided to firms and firm survival. Clearly, grants provide a financial cushion which either lower set-up costs or reduce running costs.

Industry-specific variables have been widely examined in previous work in this area. The degree of competition is expected to have an impact on firm survival, with the concentration ratio being used as a proxy in several studies. The general 
argument put forward is that increased concentration in the industry will make the environment more difficult for new entrants, leading to greater risk of failure. However, while McCloughan and Stone (1998) and Baldwin and Rafiquzzaman (1995) find a significant relationship between concentration and firm duration, Wagner (1994) finds no such relationship for German manufacturing. Wagner, arguing along the lines of Geroski (1991), suggests that local conditions, in particular, market niches, are more likely to be important to small entrants and, thus, suggests that there may well be no significant relationship between concentration and survival. Thus, previous literature is divided on the role of concentration in the survival of new firms. Examination of this role here will provide further insight into this issue.

There are a number of sectoral variables which may be expected to impact on firm duration. Sectoral output growth rates and growth in sectoral value-added are both expected to have a positive impact on survival, since increases in these variables are expected to be associated with expanded market opportunities ${ }^{12}$. In contrast sectoral wage rate increases may be expected to have a negative impact on survival, because such an increase is associated with rising costs. Finally, there may well be differences in survival rates between different industries over and above those captured by the other industry-specific variables, as some industries decline, while others expand (see for example, McCloughan and Stone

\footnotetext{
${ }^{12}$ In practice, such variables are highly correlated, since they are measuring very similar activity. As a result they are not included jointly in the analysis which follows. The final estimation reports results for those that were found to be the most important empirically.
} 
(1998), Taylor (1999), and Li and Hamblin (2003)). For this reason, industry dummy variables are included in the analysis.

Let us now consider macroeconomic variables. The unemployment rate is expected to be negatively related to survival for two reasons. First, unemployment can be considered to be a proxy for demand, with higher unemployment being associated with lower demand. Second, it is possible that high unemployment leads to an increase in the number of start-ups, particularly for very small firms. In this case setting up a firm may be seen as an alternative to employment and may be a choice of last resort. Clearly, if this is the case, then we might again expect higher unemployment in the first year of operation to lead to a greater chance of the firm dying, given that many of the start-ups are undertaken by people less well suited or with fewer skills appropriate to running a business.

Audretsch and Mahmood (1995) argue that the real interest rate may increase the likelihood of failure, although their results do not support this view. They argue that their findings may be due to the fact that most new firms do not rely on external capital. In practice, it is likely that this argument is particularly true for very small firms and we therefore expect that there will be no significant relationship between interest rates and firm survival for micro-enterprises. However, SMEs are more likely to rely on external funds and, therefore, it is possible that there will be a negative relationship between firm survival and the interest rate. A similar argument holds for exchange rates. This is a variable which has been excluded from previous studies, yet could well be important 
particularly for SMEs, given that they are more likely to face competition from abroad and to be involved with imports and exports. In general, it is to be expected that increases in the real effective exchange rate will have an adverse affect on firm survival, since such a change implies a worsening of the competitive position relative to overseas competitors. Clearly then, there are strong grounds for believing that firm-specific, industry-specific and macroeconomic variables may impact on firm survival. Furthermore, it is to be expected that such variables will impact differentially on micro-enterprises and SMEs. We now proceed to investigate these relationships.

\section{RESULTS}

Table 2 shows the results of the final versions of the model that were estimated for micro-enterprises and SMEs. The columns in Table 2 relate respectively to micro-enterprises and SMEs. A number of variables discussed in the previous section were not included in the final estimations, since they were found to be insignificant in relation to both samples. All other variables are significant to at least the $10 \%$ level, in the majority of cases the significance is $5 \%$ or higher. As can be seen from Table 2, the final specification demonstrates that firm-specific, industry-specific and macroeconomic variables have an impact on the survival of newly-established firms. Furthermore, it is evident from the results presented that there are substantial differences in the factors determining the survival of micro-enterprises compared with that of SMEs.

\section{TABLE 2 HERE}


Before considering the variables and how they impact on firm survival, it is instructive to examine the estimated hazard functions and to note the estimated value of $\rho$, the shape parameter, in each estimation. Figures 1a and 2a show the final estimated hazard functions for micro-enterprises and SMEs respectively. For both types of firms the figures show clear evidence of positive duration dependence, followed by negative duration dependence. This is borne out by examining the estimated value of $\rho$ in Table 3, which is shown to be approximately equal to 1.6 for both micro-enterprises and SMEs. This is statistically in excess of 1 and confirms that there is evidence of positive duration dependence followed by negative duration dependence ${ }^{13}$. The nature of duration dependence has received little attention in previous studies. This is surprising given that it has important implications for policies designed to assist firm survival (for a notable exception see Mahmood (2000), who also reports that new firm hazard rates follow an inverted $U$ pattern). The analysis here suggests that for both micro-enterprises and SMEs there is an increased likelihood of death in each subsequent period during the early years of establishment, but that there is then a turning point such that firms which survive beyond this point are then less likely to die in each subsequent period. The precise turning point, tp, can be determined using the following:

$$
t p=\left[\frac{(\rho-1)}{\lambda^{\rho}}\right]^{1 / \rho}
$$

\footnotetext{
${ }^{13}$ The standard errors reported in Table 3 imply 95\% confidence intervals of 1.4264 to 1.7694 for micro-enterprises and 1.3825 to 1.8525 for SMEs.
} 
Using the estimated values of $\lambda$ and $\rho$, the turning point for micro-enterprises is found to be 8.94 , while that for SMEs is 7.89. Thus, it appears that negative duration dependence takes roughly a year longer to achieve for micro-enterprises than for SMEs. Nonetheless, for both firm types the period before negative duration dependence is relatively long. This suggests that policies designed to assist firm survival should not - as is typically the case - concentrate only on the first few years of a firm's existence. Figures 1a and 2a show the estimated conditional hazard functions for the two enterprise types. These present the probabilities of death at point $\mathrm{t}$ conditional upon the firm surviving to the previous point in time. It can be seen that while the turning point for micro enterprises is later than for SMEs, the conditional probability of failure for micro enterprises is always lower than for SMEs. This lower probability of early death for micro-enterprises is also revealed by the estimated survival functions (Figures $1 \mathrm{~b}$ and $2 \mathrm{~b}$ ) which show that the approximate proportions of micro-enterprises and SMEs surviving after 10 years are $60 \%$ and $50 \%$ respectively.

\section{FIGURE 1A HERE \\ FIGURE 1B HERE}

FIGURE 2A HERE

FIGURE 2B HERE

Let us now consider the impact on duration of firm-specific variables. The results in relation to plant size are of considerable interest, particularly given that this has been a variable that has received much attention in the literature. The results presented here for SMEs are consistent with previous studies in that they 
provide evidence of a positive relationship between plant size and firm survival. In contrast, very small firms (those with total employment of 10 or less) are less likely to survive as start-up plant size increases. The findings offer strong evidence of differences in duration behaviour for the two sub-groups of firms. There thus appears to be a threshold level below which increased plant size is a burden on firms, suggesting that previous studies, which aggregated microenterprises with SMEs may have overlooked an important issue.

For both micro-enterprises and SMEs the initial ownership status of the firm was not found to have a significant impact on survival, ${ }^{14}$ this is consistent with the results of Matta and Portugal (2002) who compared Portuguese domestic and foreign firms. They found that, after controlling for a limited number of firm and industry characteristics, there were no significant differences in the failure probabilities of the two firm types. Interestingly, our results suggest that foreign owned plants are more likely to survive, but, that this is due to their relatively larger size at establishment rather than their ownership status ${ }^{15}$.

It is clearly possible that the difference in results between micro-enterprises and SMEs is reflecting differences in ownership, rather than size at establishment. To investigate this, and to test the robustness of the results presented in Table 2, two

\footnotetext{
${ }^{14}$ With respect to micro-enterprises the results are, perhaps, not surprising, given that only $6 \%$ were UK owned and that just $2 \%$ were initially under foreign ownership.

${ }^{15}$ This stands in contrast to the results of Gorg and Strobl (2003) who suggest that multinational plants are more 'footloose' than locally owned plants after controlling for plant- and industryspecific characteristics.
} 
additional regressions were estimated. These equations were estimated using only local observations, hence removing the issue of interactions between size and ownership, and are reported in Table $3^{16}$. Within this local sub-sample the same size effects are observed as in the entire sample, namely a negative relationship between size at establishment and survival for micro-enterprises and a positive one for $\mathrm{SMEs}^{17}$. The other parameter estimates within these regressions also exhibit identically signed coefficients to those within Table 2, with the exception of the change in exchange rate variable (which also relates to a different period in this second set of regressions) and also some differences in the industry dummies which are though to reflect the make-up of plants by industry within the sub-sample.

\section{TABLE 3 HERE}

Returning to the main results in Table 2, there was no evidence that the provision of grants to newly-established firms has an impact on either firm type. Finally, in relation to firm-specific variables, it is worth noting that the specific location

\footnotetext{
${ }^{16}$ Equivalent estimations were not feasible for non-local enterprises due to an insufficient number of observations.

${ }^{17}$ It should be noted that the size effect for SMEs was significant at only the $14 \%$ level. This may be due to the lack of 'large' SMEs within the local sub sample. The average size of the local SME was 21 employees, this compares to 31 for a UK owned SME and 38 for a foreign owned SME.
} 
within the Wearside sub-region did not impact on firm duration ${ }^{18}$. This may appear at first sight to be somewhat surprising given the contrasting characteristics of Sunderland and Washington. The former has, over the period of analysis, shed a very substantial number of jobs and faced severe problems following the decline of traditional industries. While Washington, as a new town, not only had a Development Corporation during some of the period analysed, but also benefited from better transport links and other infrastructure advantages. While old industries ${ }^{19}$ based in Sunderland were adversely affected during the 1970s and 1980s, the results suggest that there was not a significantly higher failure rate among newly-established manufacturing firms in Sunderland compared to their counterparts in other areas. This could be due, in part, to the fact that at the same time as the old industries were in decline in Sunderland, there was substantial investment in improving its infrastructure from the early 1980s, in particular via the activities of the Tyne \& Wear Urban Development Corporation.

To summarise thus far: it is clear that, as far as firm-specific variables are concerned increased plant size has a negative impact on the survival of microenterprises, but a positive impact on the survival of SMEs. Ownership variables, location and the receipt of grants do not have a significant influence on survival chances.

\footnotetext{
${ }^{18}$ In the interests of brevity, the results for the estimations including the location dummies are not reported. Inclusion of these dummies did not change the overall pattern of results. Results available on request.

${ }^{19}$ Established prior to our sample.
} 
Turning to industry-specific factors, the sectoral growth rate, over the first three years after establishment of operations, was found to be of importance. The coefficient is of the expected sign, in that higher sectoral growth in the first few years of operations is associated with longer survival. This was found to be highly significant for both enterprise types, broadly in line with the findings, for the USA, of Audretsch and Mahmood (1995). It is particularly noteworthy that the coefficients for the concentration ratio were not significant. While some previous studies have found the concentration ratio at the date of establishment to be significant, the results presented here are consistent with those for German manufacturing presented in Wagner (1994). As Wagner argues, economy-wide industry-specific indicators are unlikely to be a good proxy for influences of competition and 'the lack of explanatory power of industry characteristics in the survival models is not surprising at all'. (1994, p147). Thus, in relation to industry-specific variables, there is clear evidence of differences across industries, but little relating to other industry-specific influences on firm survival.

The industry dummy variables clearly show that there are some significant differences across industries. For SMEs there is clear evidence of a negative effect associated with the textile industry and a positive effect in the rubber and plastics industry. For micro-enterprises there is a negative effect in the furniture industry and a positive effect in the miscellaneous manufacturing sector.

Finally, we turn to macroeconomic variables. Three interest rate variables were included in the final estimations: the real short-term interest rate in the year in 
which the firm was established, the change in the short-term interest rate from the first to second year and the change in the real interest rate from the second to third year ${ }^{20}$. The real interest rate at establishment was significant for both micro firms and SMEs. While the micro-enterprise coefficient has the expected negative sign, the effect is positive for SMEs. There are various possible explanations for this: (1) higher interest rates are typically associated with times of high aggregate demand, and this positive effect is dominating the negative interest rate effect; (2) it is conceivable that this coefficient is picking up a screening effect, where more marginal SMEs are less likely to be established when interest rates are high due to higher opportunity costs of capital and credit rationing effects, hence high interest rates (at start-up) creates a cohort of SMEs with lower than otherwise probabilities of failure. Changes in the interest rate from the first to second and second to third year were found to be significant for micro-enterprises. Again the interest rate effects had the anticipated sign. The difference between the impact on micro-enterprises and SMEs is in line with expectations. Thus the results presented here suggest that low and stable interest rates are important in helping micro-enterprises to survive. The final variables found to be significant relate to changes in the exchange rate. However, this is only significant for micro-enterprises. The change in the real effective exchange rate, from the second to the third year was found to be significant and to have the expected sign. The unemployment rate, either that for the region, or the UK as a whole, was found to be an insignificant variable for both enterprise types. To

\footnotetext{
${ }^{20}$ Long-term interest rates were also included, but were found to have an insignificant impact. In addition, changes in the real short-term interest rate in other years were also examined, but also found to have no significant effect.
} 
summarise: macroeconomic variables do have an impact on both enterprise types, but the effects are more complex for micro-enterprises than for SMEs.

\section{CONCLUSION}

This paper has analysed firm survival for newly-established firms in the NorthEast region of England, using a unique data set of 781 firms. This study is distinguished from previous work in that it estimates hazard functions separately for micro-enterprises and SMEs. This division of the data was undertaken because there are strong grounds for believing that economic factors will impact differentially on the two firm types. The distinction between the two types of firms is found to be important, with variables having a substantially differential impact on micro-enterprises and SMEs. Further, the results presented here demonstrate that firm-specific, macroeconomic and industry-specific variables have important implications for firm survival.

In line with prior expectations, increases in intial plant size are seen to have a positive impact on the survival of SMEs. However, increases in plant size were found to impact negatively on micro-enterprise durations. In contrast to the findings of some research, ownership of the enterprise was not identified as a significant firm-specific variable. Our results suggest that the longer survival durations associated with foreign ownership are a function of larger sizes at establishment rather than ownership per se.

As far as macroeconomic variables are concerned, higher rates of unemployment were not associated with survival chances. This finding would appear to be 
incompatible with the view that micro-enterprises are often set up as an alternative of last resort for individuals facing unemployment. The other key macroeconomic variables that emerged from the study were interest rates and exchange rates. For micro-enterprises, low interest rates at establishment enhance firm survival, while beyond the first year of operation, increases in the real interest and exchange rates impact negatively on their survival probabilities.

Both micro-enterprises and SMEs exhibited clear evidence of initial positive duration dependence, followed by negative duration dependence - enterprises displayed increased probabilities of death for the first eight to nine years. These findings are particularly interesting in the context of current debates in the UK concerning support for small firms. First of all, they suggest that policies to assist survival should concentrate on more than just the first few years. After all, the probability of death rises for almost the first decade of operations. Secondly, there is the possibility that encouraging the rapid expansion of micro-enterprises as a mechanism for economic growth and development, may inadvertently increase the probability of failure for these business. 
The authors are grateful to Tony Antoniou, Peter Johnson, Simon Parker, Martin Robson David Storey and Colin Wren for helpful comments on an earlier draft. The authors are particularly grateful to Paul Braidford for extensive help with the data for this paper. The usual disclaimer applies 


\section{References}

Agarwal, R. (1998). ‘Small firm survival and technological activity’, Small Business Economic,s 11, pp. 215-24

Arrighetti, A. and Vivarelli, M. (1999). 'The rôle of innovation in the postentry performance of new small firms: Evidence from Italy', Southern Economic Journal, 65, pp. 927-39

Audretsch, D.B. (1995). 'The propensity to exit and innovation', Review of Industrial Organization, 10, pp. 589-605

Audretsch, D.B. and Mahmood, T. (1994). 'Firm selection and industry evolution: The post-entry performance of new firms', Journal of Evolutionary Economics, 4, pp. 243-60

Audretsch, D.B. and Mahmood, T. (1995). 'New-firm survival: New results using a hazard function', Review of Economics and Statistics, 77, pp. 97-103

Audretsch, D.B., Santarelli, E. and Vivarelli, M. (1999). 'Start-up size and industrial dynamics: some evidence from Italian manufacturing', International Journal of Industrial Organization, 17, pp. 965-83

Baldwin, J.R. and Rafiquzzaman, M. (1995). 'Selection versus evolutionary adaptation: Learning and post-entry performance', International Journal of Industrial Organization, 13, pp. 501-22

Disney, R., Haskel, J. and Heden, Y. (2003). 'Entry, Exit and Establishment Survival in UK Manufacturing', Journal of Industrial Economics, 51, pp. 91122. 
Dunne, P. and Hughes, A. (1992). 'Age, size, growth and survival: UK companies in the 1980s', Journal of Industrial Economics, 42, pp. 115-40

Dunne, T., Roberts, M.J. and Samuelson, L. (1988). 'Patterns of firm entry and exit in US manufacturing industries', Rand Journal of Economics, 104, pp. 671-98

Fotopoulos, G. and Louri, H. (2000) 'Location and Survival of New Entry', Small Business Economics, 14, pp. 311-21

Gorg, H. and Strobl, E. (2003) 'Multinational Companies, Technology Spillovers and Plant Survival' The Scandinavian Journal of Economics, 105, pp. 581-95

Geroski, P.A. (1991). Market Dynamics and Entry, Blackwell, Oxford

Li, X. and Hamblin, D. J. (2003) 'The Impact of Performance and Practice Factors on UK Manufacturing Companies' Survival' International Journal of Production Research, 41, pp. 963-79

Mahmood, T. (2000) 'Survival of Newly Founded Businesses: A Log-Logistic Model Approach' Small Business Economics, 14, pp. 223-37 volme

Mata, J. and Audretsch, D.B. (eds.) (1995). 'The Post-Entry Performance of Firms', special issue of International Journal of Industrial Organization, 13, pp. $413-614$

Mata, J. and Portugal, P. (1994). 'Life duration of new firms', Journal of Industrial Economics, 42, pp. 227-45

Mata, J. and Portugal, P. (2002). 'The Survival of New Domestic and Foreign Firms', Strategic Management Journal, 23, pp. 323-43 
McCloughan, P. and Stone, I. (1998). 'Life duration of foreign multinational subsidiaries: Evidence from UK northern manufacturing industry 1970-93', International Journal of Industrial Organization, 16, pp. 719-48

Perez, S. E., Llopis, A. S. and Llopis, J. A. S. (2004) 'Determinants of Survival of Spanish Manufacturing Firms' Review of Industrial Organization, 25, pp. $251-73$

Person, H. (2004) 'The Survival and Growth of New Establishments in Sweden, 1987-1995' Small Business Economics, 23, pp. 423-40

Reid, G.C. (1991). 'Staying in Business', International Journal of Industrial Organization, 9 , pp. $545-56$

Segarra, A. and Callejon, M. (2002) 'New Firms' Survival and Market Turbulance: New Evidence from Spain' Review of Industrial Organisation, 20, pp. $1-14$

Stone, I. and Peck, F. (1996). 'The foreign-owned manufacturing sector in UK peripheral regions, 1978-1993: restructuring and comparative performance', Regional Studies, 30, pp. 55-68

Stone, I., Braidford, P. and Allinson, G. (2004) 'Small Business Succession: An International Literature Review', Annex to Small Business Service, Passing the Baton - Encouraging Successful Business Transfers. Department of Trade and Industry, HMSO London

Storey, D.J. (1990). 'Evaluation of policies and measures to create local employment', Urban Studies 27, pp. 669-84

Taylor, M.P. (1999). 'Survival of the Fittest? An Analysis of Self-Employment Duration in Britain', Economic Journal 109, pp.140-55 
Wagner, J. (1994). 'The post-entry performance of new small firms in German manufacturing industries', Journal of Industrial Economics 42, pp. 141-54 
Table 1: Number of firms established by start-up date and status in 2002

\begin{tabular}{|l|r|r|r|}
\hline Sub period & \multicolumn{2}{|c|}{$\begin{array}{c}\text { Number of } \\
\text { firms }\end{array}$} & \multicolumn{2}{|c|}{ Status in 2002 } \\
\cline { 3 - 4 } & established & Number alive & $\begin{array}{c}\text { \% Alive } \\
\text { (Truncated) }\end{array}$ \\
\hline $1973-80$ & 236 & 55 & 23.3 \\
\hline $1981-85$ & 299 & 125 & 41.8 \\
\hline $1986-90$ & 131 & 58 & 44.3 \\
\hline $1991-95$ & 70 & 37 & 52.9 \\
\hline $1996-2001$ & 45 & 43 & 95.6 \\
\hline Total & 781 & 318 & 40.7 \\
\hline
\end{tabular}


Table 2: Log-logistic hazard model estimates of the determinants of firm survival for micro-enterprises and SMEs

\begin{tabular}{|c|c|c|}
\hline $\begin{array}{l}\text { Variable } \\
\quad \text { Constant }\end{array}$ & $\begin{array}{r}\text { enterprises } \\
2.8391 \\
\star \star \star 0.1234\end{array}$ & $\begin{array}{l}\text { SMEs } \\
2.0621 \\
* * * 0.1439\end{array}$ \\
\hline \multicolumn{3}{|l|}{ Firms specific variables: } \\
\hline Plant Size & $\begin{array}{l}-0.0670 \\
* * \star 0.0240\end{array}$ & $\begin{array}{r}0.0166 \\
* * * 0.00577\end{array}$ \\
\hline \multicolumn{3}{|l|}{ Macroeconomic variables: } \\
\hline Real interest rate - year 1 & $\begin{array}{l}-0.0405 \\
{ }^{* *} 0.0185\end{array}$ & $\begin{array}{l}0.0395 \\
* 0 \\
* 0.0184\end{array}$ \\
\hline $\begin{array}{l}\text { Change in real interest rate - first year to } \\
\text { second year }\end{array}$ & $\begin{array}{r}-0.0308 \\
{ }^{*} 0.0170\end{array}$ & \\
\hline $\begin{array}{l}\text { Change in real interest rate - second year to } \\
\text { third year }\end{array}$ & $\begin{array}{r}-0.0323 \\
{ }^{*} 0.0166\end{array}$ & \\
\hline $\begin{array}{l}\text { Change in exchange rate- second year to } \\
\text { third year }\end{array}$ & $\begin{array}{r}0.0154 \\
* * 0.00739\end{array}$ & \\
\hline \multicolumn{3}{|l|}{ Industry specific variables: } \\
\hline Sectoral growth rate - years 1 to 3 & $\begin{array}{r}1.4746 \\
* \star * 0.4689\end{array}$ & $\begin{array}{r}1.9422 \\
\star \star \star * 0.7182\end{array}$ \\
\hline Manufacture of wearing apparel & & $\begin{array}{l}-1.4565 \\
\star * \star 0.2294\end{array}$ \\
\hline Manufacture of rubber and plastic products & & $\begin{array}{r}1.0958 \\
\star * \star 0.4156\end{array}$ \\
\hline $\begin{array}{l}\text { Manufacture of machinery and equipment not } \\
\text { elsewhere classified }\end{array}$ & $\begin{array}{r}0.4171 \\
\star \star \star 0.1476\end{array}$ & \\
\hline Manufacture of furniture & $\begin{array}{l}-0.3805 \\
* * * 0.1300\end{array}$ & \\
\hline Sigma & $\begin{array}{r}0.6258 \\
* \star * 0.0343\end{array}$ & $\begin{array}{r}0.6182 \\
\star \star \star \\
* 0.0458\end{array}$ \\
\hline Number of observations & 232 & 547 \\
\hline $\begin{array}{l}\rho \\
(\mathrm{se})\end{array}$ & $\begin{array}{r}1.5979 \\
0.0875\end{array}$ & $\begin{array}{r}1.6175 \\
0.1199\end{array}$ \\
\hline $\begin{array}{l}\lambda \\
\text { (se) }\end{array}$ & $\begin{array}{l}0.0811 \\
0.00404\end{array}$ & $\begin{array}{r}0.0953 \\
0.0079\end{array}$ \\
\hline Log-likelihood & -637.0381 & -262.2127 \\
\hline
\end{tabular}


Table 3: Log-logistic hazard model estimates of the determinants of locally owned firm survival for micro-enterprises and SMEs

\begin{tabular}{|c|c|c|}
\hline $\begin{array}{l}\text { Variable } \\
\quad \text { Constant }\end{array}$ & $\begin{array}{c}\text { Local } \\
\text { Micro- } \\
\text { enterprises } \\
2.7900 \\
* \star \star 0.0252\end{array}$ & $\begin{array}{r}\text { Local SMEs } \\
2.2034 \\
* \star 0.0152\end{array}$ \\
\hline \multicolumn{3}{|l|}{ Firms specific variables: } \\
\hline Plant Size & $\begin{array}{l}-0.0678 \\
* \star * 0.0252\end{array}$ & $\begin{array}{l}0.0106 \\
0.00713\end{array}$ \\
\hline \multicolumn{3}{|l|}{ Macroeconomic variables: } \\
\hline Real interest rate - year 1 & $\begin{array}{r}-0.0461 \\
{ }^{*} 0.0204\end{array}$ & $\begin{array}{r}0.0475 \\
* 0.0248\end{array}$ \\
\hline $\begin{array}{l}\text { Change in real interest rate - first year to } \\
\text { second year }\end{array}$ & $\begin{array}{l}-0.0447 \\
{ }^{*} 0.0195\end{array}$ & \\
\hline $\begin{array}{l}\text { Change in real interest rate - second year to } \\
\text { third year }\end{array}$ & $\begin{array}{r}-0.0323 \\
* 0.0179\end{array}$ & \\
\hline $\begin{array}{l}\text { Change in exchange rate- first year to second } \\
\text { year }\end{array}$ & $\begin{array}{l}-0.0135 \\
{ }^{* *} 0.00651\end{array}$ & \\
\hline \multicolumn{3}{|l|}{ Industry specific variables: } \\
\hline Sectoral growth rate - years 1 to 3 & $\begin{array}{r}1.0268 \\
* \star 0.5300\end{array}$ & $\begin{array}{r}1.8033 \\
\star * 0.8034\end{array}$ \\
\hline Manufacture of wearing apparel & & $\begin{array}{l}-0.6918 \\
* \star 0 \\
* 0.3853\end{array}$ \\
\hline Manufacture of rubber and plastic products & $\begin{array}{r}0.4438 \\
{ }^{0} 0.2136\end{array}$ & \\
\hline $\begin{array}{l}\text { Manufacture of machinery and equipment not } \\
\text { elsewhere classified }\end{array}$ & $\begin{array}{l}0.3764 \\
{ }^{*} 0.1589\end{array}$ & \\
\hline Manufacture of furniture & $\begin{array}{l}-0.3725 \\
* * * 0.1342\end{array}$ & \\
\hline Manufacture of fabricated metal products & & $\begin{array}{l}-1.4606 \\
* * \star 0,2557\end{array}$ \\
\hline Sigma & $\begin{array}{r}0.6309 \\
* * * 0.0363\end{array}$ & $\begin{array}{r}0.5758 \\
\star \star * \\
* 0.0485\end{array}$ \\
\hline Number of observations & 502 & 160 \\
\hline $\begin{array}{l}\rho \\
\text { (se) }\end{array}$ & $\begin{array}{r}1.5849 \\
0.0913\end{array}$ & $\begin{array}{r}0.1165 \\
0.0105\end{array}$ \\
\hline $\begin{array}{l}\lambda \\
\text { (se) }\end{array}$ & $\begin{array}{r}0.0805 \\
0.0042\end{array}$ & $\begin{array}{r}1.7366 \\
0.1463\end{array}$ \\
\hline Log-likelihood & -584.7601 & $\begin{array}{r}0.1463 \\
-183.5980\end{array}$ \\
\hline
\end{tabular}


Figure 1a: Estimated Hazard Function for Micro-Enterprises

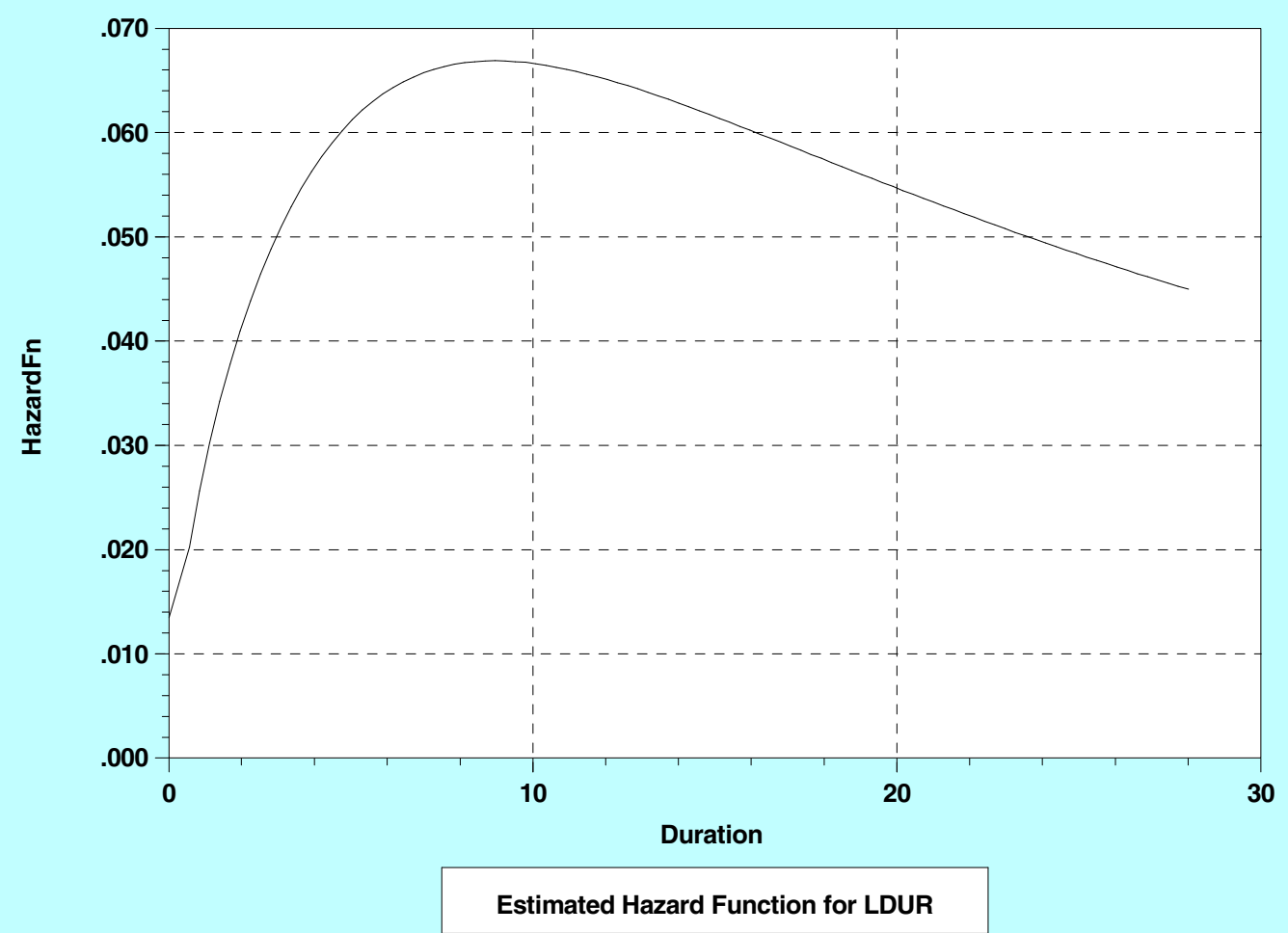


Figure 1b: Estimated Survival Function for Micro-Enterprises

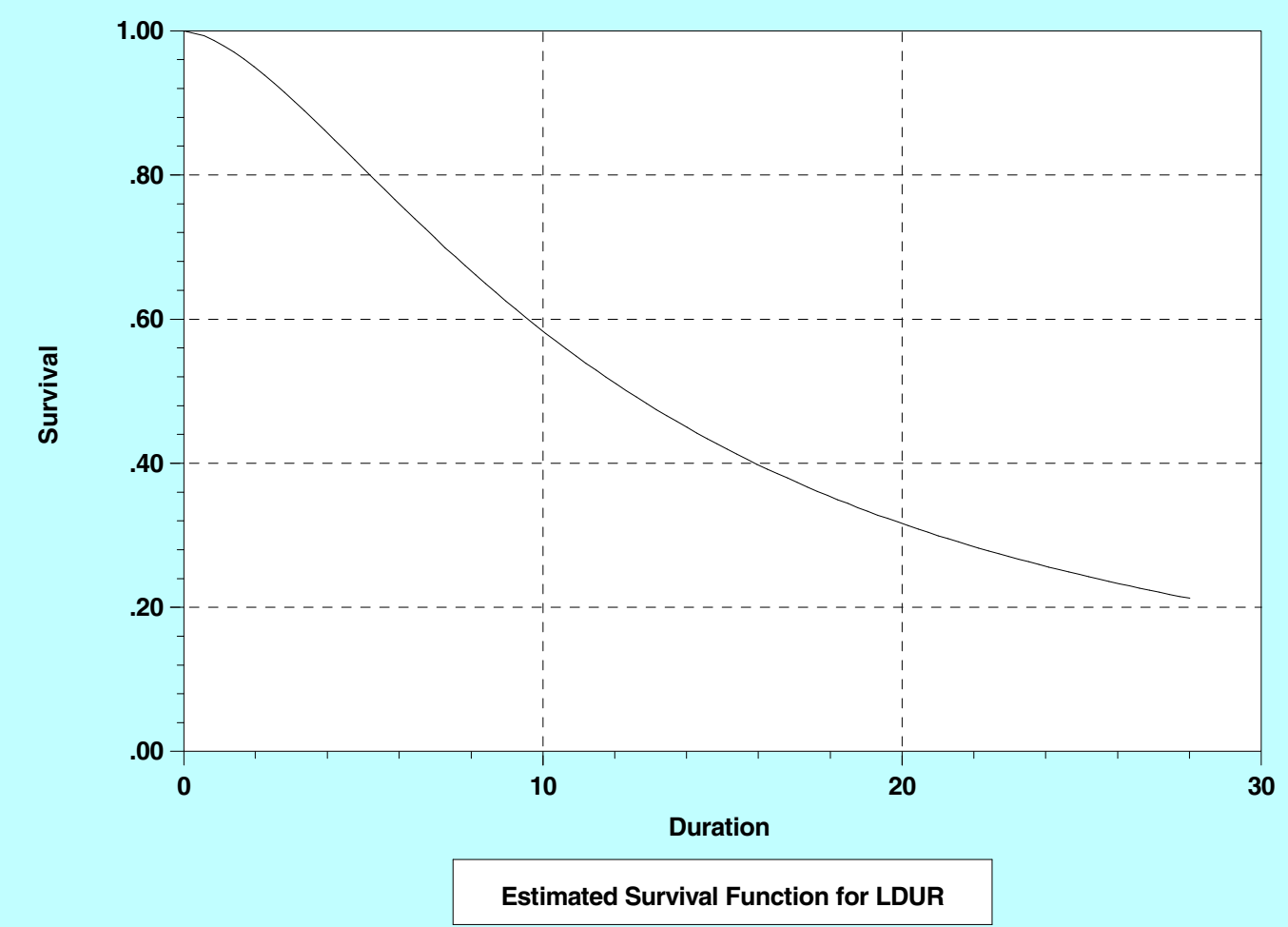


Figure 2a: Estimated Hazard Function for SMEs

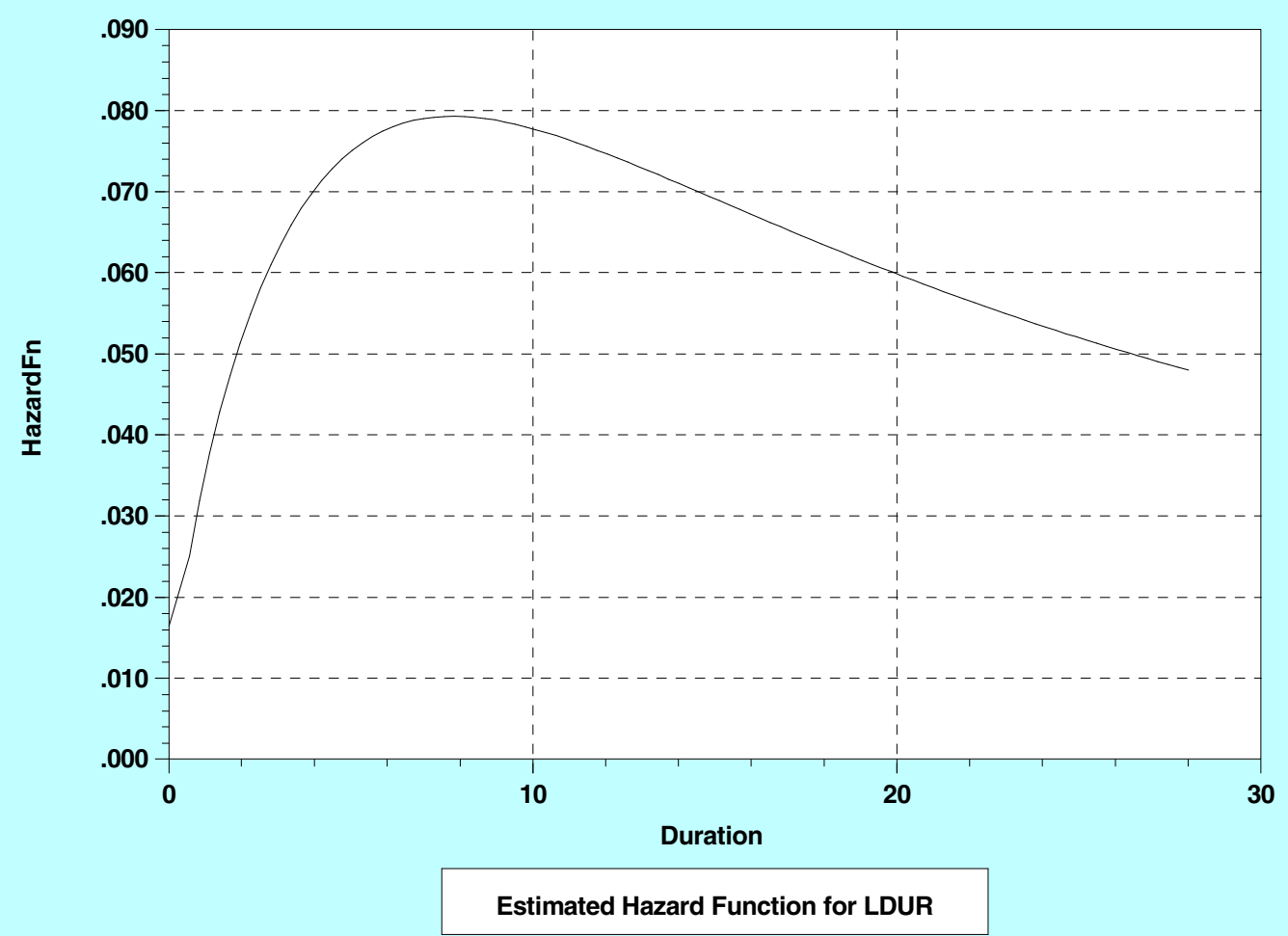


Figure 2b: Estimated Survival Function for SMEs

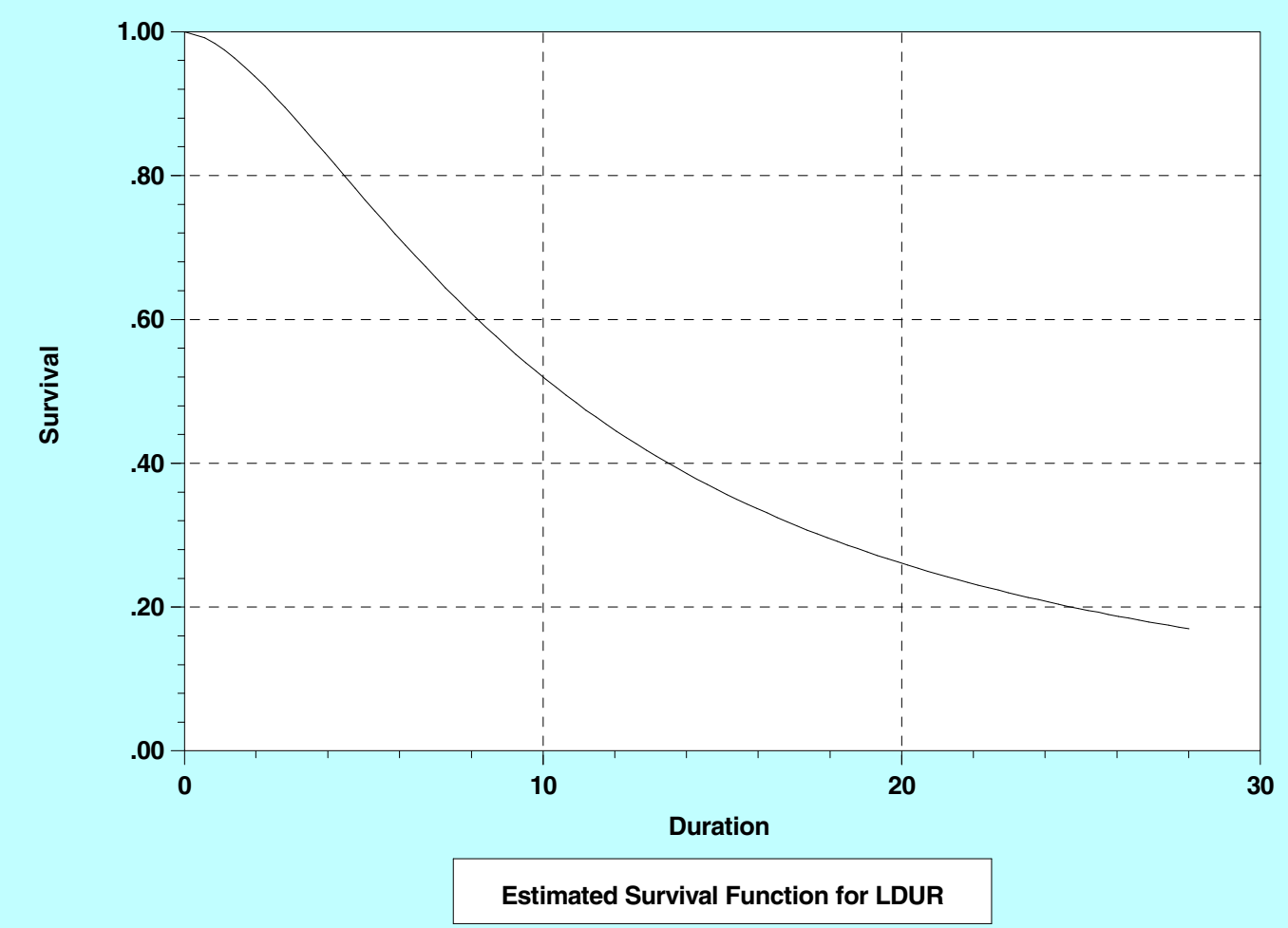

